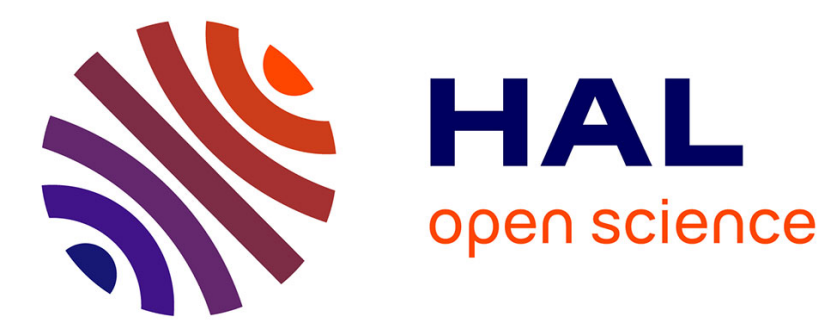

\title{
Poly(ethylene) glycols and mechanochemistry for the preparation of bioactive 3,5-disubstituted hydantoins
}

Laure Konnert, M. Dimassi, Lori Gonnet, Frédéric Lamaty, Evelina Colacino

\section{To cite this version:}

Laure Konnert, M. Dimassi, Lori Gonnet, Frédéric Lamaty, Evelina Colacino. Poly(ethylene) glycols and mechanochemistry for the preparation of bioactive 3,5-disubstituted hydantoins. RSC Advances, 2016, 6 (43), pp.36978-36986. 10.1039/c6ra03222b . hal-02385431

\section{HAL Id: hal-02385431 \\ https://hal.science/hal-02385431}

Submitted on 28 Nov 2019

HAL is a multi-disciplinary open access archive for the deposit and dissemination of scientific research documents, whether they are published or not. The documents may come from teaching and research institutions in France or abroad, or from public or private research centers.
L'archive ouverte pluridisciplinaire HAL, est destinée au dépôt et à la diffusion de documents scientifiques de niveau recherche, publiés ou non, émanant des établissements d'enseignement et de recherche français ou étrangers, des laboratoires publics ou privés. 


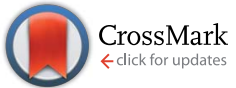

Cite this: RSC Adv., 2016, 6, 36978

Received 3rd February 2016

Accepted 1st April 2016

DOI: $10.1039 / c 6 r a 03222 b$

www.rsc.org/advances

\section{Poly(ethylene) glycols and mechanochemistry for the preparation of bioactive 3,5-disubstituted hydantoins $\uparrow$}

\author{
L. Konnert, M. Dimassi, L. Gonnet, F. Lamaty, J. Martinez and E. Colacino*
}

Mechanochemistry was effective for the preparation of 3,5-disubstituted hydantoins from $\alpha$-amino methyl esters, using either $1,1^{\prime}$-carbonyldiimidazole (CDI) or alkyl isocyanates. The preparation of the antimicrobial additives, 3-allyl-5,5'-dimethyl hydantoin (ADMH) and 1-chloro-3-ethyl-5,5'-dimethyl hydantoin (CEDMH) were performed by grinding. A chlorination reaction, never described before by mechanochemistry was achieved by $\mathrm{Ca}(\mathrm{ClO})_{2}$, while the preparation of the bioactive anticonvulsant marketed drug ethotoin was achieved by a novel approach based on poly(ethylene) glycol (PEGs) assisted grinding.

\section{Introduction}

Hydantoins or 2,4-imidazolidinediones are a well-known family of bioactive compounds with numerous therapeutic properties. ${ }^{1}$ Among the diversity of potential structures due to the high degree of possible substitutions of the hydantoin core, 3,5disubstituted hydantoins show particularly interesting biological activities. Marketed drugs contain a hydantoin scaffold, notably the anticonvulsant drug ethotoin, ${ }^{2}$ the androgen receptor antagonist nilutamide, ${ }^{3}$ or the antimicrobial additives for polymer textiles and medical applications 1-chloro-3-ethyl5,5-dimethyl hydantoin (CEDMH $)^{4}$ and 3-allyl-5,5'-dimethylhydantoin (ADMH) ${ }^{5}$ (Fig. 1).

Various methodologies have been applied to the synthesis of 3,5-disubstituted hydantoins. A straightforward pathway is the alkylation/arylation ${ }^{6-10}$ of the N-3 position of $5^{-}$or $5,5^{\prime}$-disubstituted hydantoins but most of the procedures describe the cyclisation of ureido derivatives of amino esters $\mathbf{A}$, prepared by reaction with isocyanates (either in solution ${ }^{11-17}$ or on solidsupport $^{18-23}$ ) (Method A, Scheme 1), phosgene, ${ }^{24}$ or triphosgene. ${ }^{25-29}$

We have recently demonstrated that mechanochemistry was successfully applied to the eco-friendly preparation of $5,5^{\prime}$ disubstituted hydantoins, ${ }^{30}$ including the antiepileptic drug phenytoin (Phenytek®, Fig. 1). We present herein a general and unprecedented mechanochemical approach to access 3,5disubstituted hydantoins from $\alpha$-amino esters, via an ureido

Institut des Biomolécules Max Mousseron (IBMM), UMR 5247 CNRS - UM - ENSCM, Green Chemistry and Enabling Technology Team, Université de Montpellier, Campus Triolet, Place E. Bataillon, 34095 Montpellier Cedex 5, France. E-mail: evelina. colacino@umontpellier.fr

$\dagger$ Electronic supplementary information (ESI) available: General remarks, technical details and characterization of all compounds and spectral data $\left({ }^{1} \mathrm{H}\right.$ NMR, ${ }^{13} \mathrm{C}$ NMR and IR). Chiral HPLC analyses of compounds 4. See DOI: 10.1039/c6ra03222b derivative A (Method A, Scheme 1), obtained from the corresponding isocyanate. This ureido derivative A could also be obtained via an original route, from $N$-carbamoyl imidazole activated amino ester derivative B (Method B, Scheme 1), by reaction with various amines. Molecules such as 1-chloro-3ethyl-5,5-dimethyl hydantoin (CEDMH), ${ }^{4}$ 3-allyl-5,5'-dimethylhydantoin $(\mathrm{AMDH})^{5}$ and the anticonvulsant drug ethotoin were synthesized. An unprecedented mechanochemical chlorination reaction was achieved with $\mathrm{Ca}(\mathrm{ClO})_{2}$ with better results when compared with solution syntheses. In the case of ethotoin, three synthetic strategies have been explored in a ball-mill (BM), including the poly(ethylene) glycols-assisted grinding approach, ${ }^{31,32}$ applied for the first time to access Active Pharmaceutical Ingredients (API).
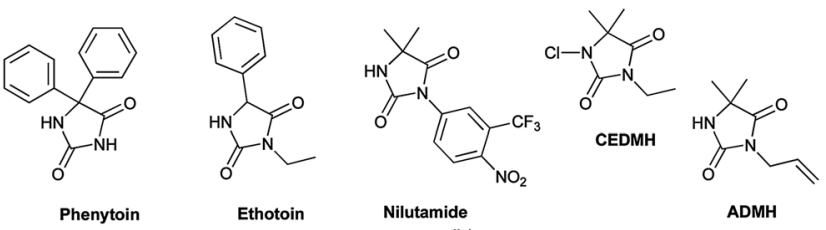

(Phenytek")

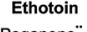

(Anandron"

ADMH

Fig. 1 Drugs with $\mathrm{N}$ - and/or C-disubstituted hydantoin structure.

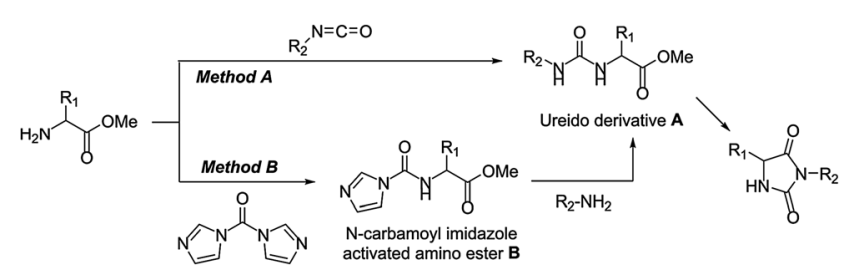

Scheme 1 Possible routes to 3,5-disubstituted hydantoins via ureido derivatives of amino esters. 


\section{Results and discussion}

The mechanochemical preparation of 3-ethyl-5-benzyl hydantoin 2 was first investigated, according to a one-pot/two step procedure based on Method B (Scheme 1). Phenylalanine methyl ester hydrochloride was reacted with CDI in a planetary ball-mill (PBM), leading to the corresponding $1 H$-imidazolecarboxamido derivative 1 (Table 1). Milling the mixture in the presence of ethylamine hydrochloride - added in the second step - resulted in the unsymmetrical urea 3 that was converted into the hydantoin 2 by base-mediated intramolecular cyclization, using stoichiometric amounts of solid $\mathrm{K}_{2} \mathrm{CO}_{3}$. Selected data for the optimization of the reaction conditions are reported in Table 1.

In the first trial (entry 1), the starting amino ester was not fully converted into the intermediate $\mathbf{1}$ and a symmetrical urea species of phenylalanine methyl ester was formed, resulting in a reduced yield (65\%) of the desired product 3-ethyl-5-benzylhydantoin 2 . Results were not improved when the milling speed was increased to $750 \mathrm{rpm}(66 \%)$ or by adding ethylamine hydrochloride in excess (64\%). Extending the reaction time during the first step (entry 2) resulted in a lower yield (52\%) of 2 , due to the formation of increased amounts of symmetrical urea. This trend was also observed when adding either CDI or amino ester portion-wise and seemed to be emphasized when CDI was present in excess (entries 1 and 2). When the amount of CDI was decreased (1.3 equiv.) and the number of balls in the jar was

Table 1 Screening of the conditions for the preparation of 3-ethyl-5benzyl hydantoin 2 (Method B) $^{a}$

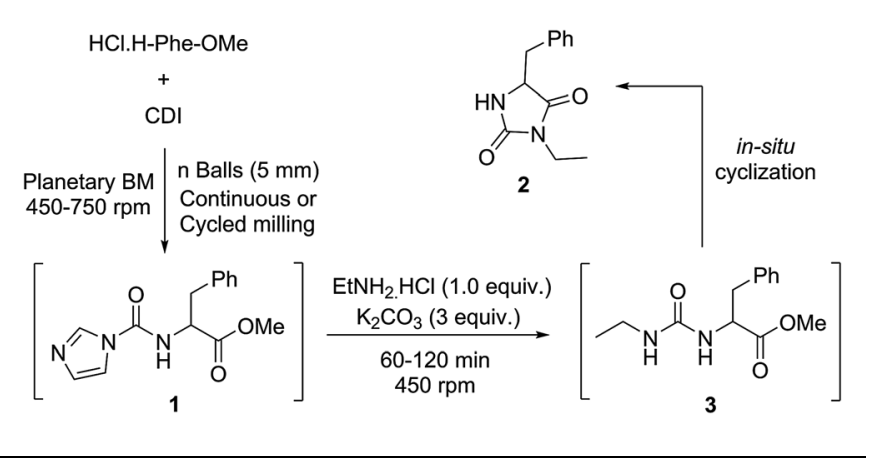

\begin{tabular}{|c|c|c|c|c|c|}
\hline \multirow[b]{2}{*}{ Entry } & \multirow[b]{2}{*}{ CDI (equiv.) } & \multirow[b]{2}{*}{ Balls $(n)$} & \multicolumn{2}{|c|}{ Conditions (min) } & \multirow[b]{2}{*}{ Yield $^{b}(\%)$} \\
\hline & & & Step 1 & Step 2 & \\
\hline 1 & 2 & 25 & 10 & 120 & 65 \\
\hline 2 & 2 & 25 & 60 & 120 & 52 \\
\hline 3 & 1.3 & 50 & 40 & 60 & 84 \\
\hline 4 & 1.3 & 50 & $60,8 \times\left(5^{\prime} / 2^{\prime}\right)^{c}$ & 60 & 77 \\
\hline 5 & 1.1 & 50 & $60,8 \times\left(5^{\prime} / 2^{\prime}\right)^{c}$ & 120 & 67 \\
\hline 6 & 1.3 & 50 & 40, EtOAc $^{d}$ & 120 & 75 \\
\hline
\end{tabular}

${ }^{a}$ The reactions were performed in a stainless steel jar (using stainless steel balls, $5 \mathrm{~mm} \varnothing$ ) at $450 \mathrm{rpm}$ under continuous milling except when otherwise stated. ${ }^{b}$ Isolated yields. ${ }^{c}\left(x^{\prime} / y^{\prime}\right)$ : the reaction mixture was cycle-milled for 40 minutes during 8 cycles of 5 minutes followed by 2 minute standby, with reverse rotation between two cycles. ${ }^{d} 400$ $\mu \mathrm{L}\left(\eta=0.37 \mu \mathrm{L} \mathrm{mg}^{-1}\right)$ of EtOAc were added. doubled (50), after precipitation in water, hydantoin 2 was obtained in a better yield (84\%, entry 3). Neither cycled milling ${ }^{30,33,34}$ (entries 4 and 5) nor decreasing the amount of CDI (entry 5) or Liquid-Assisted Grinding (LAG) with ethyl acetate (entry 6), improved the yield of the reaction.

The reaction was investigated with other combinations of $\alpha$ amino esters/amines (Table 2, Method B). Both allyl and benzylamine reacted smoothly with phenylalanine imidazolecarboxamido derivative $\mathbf{1}$ affording the corresponding hydantoins (13 and 18 respectively) in good yields. The reactivity of the system was not influenced by the physical state (solid or liquid) of the amine as also confirmed by leucine (compounds 4 and 19) and aminoisobutyric (Aib) methyl ester (compounds 11 and 16). However, it seemed that the steric and electronic nature of the entering amine drove the outcome of the reaction.

Indeed, hydantoin 24 was obtained in moderate yield (49\%) when cyclohexylamine (c-Hex- $\mathrm{NH}_{2}$ ) was tested, while no reaction was observed in the presence of the sterically hindered

Table 2 Preparation of 3,5-disubstituted hydantoins following Method B and Method A

\begin{tabular}{|c|c|c|c|c|c|}
\hline \multirow[b]{3}{*}{$\mathrm{R}^{1}$} & \multirow[b]{3}{*}{$\mathrm{R}^{2}$} & \multirow[b]{3}{*}{ Product } & \multicolumn{3}{|c|}{ Yield $^{a, b}(\%)$} \\
\hline & & & \multicolumn{2}{|l|}{$\mathrm{B}^{c}$} & \multirow{2}{*}{$\frac{\mathrm{A}^{d}}{\mathrm{NC}^{e}}$} \\
\hline & & & $\mathrm{NC}^{e}$ & $\mathrm{RC}^{e}$ & \\
\hline $\mathrm{CH}_{2} \mathrm{Ph}$ & $\mathrm{CH}_{2} \mathrm{CH}_{3}$ & $2^{f}$ & 84 & n.p..$^{g}$ & 75 \\
\hline $\mathrm{CH}_{2} \mathrm{CH}\left(\mathrm{CH}_{3}\right)_{2}$ & $\mathrm{CH}_{2} \mathrm{CH}_{3}$ & 4 & $61(70)^{h}$ & $76(70)^{h}$ & $83(90)^{h}$ \\
\hline $\mathrm{CH}_{2} \mathrm{Ph}\left(p-\mathrm{O}^{t} \mathrm{Bu}\right)$ & $\mathrm{CH}_{2} \mathrm{CH}_{3}$ & 5 & 56 & 82 & 82 \\
\hline$\left(\mathrm{CH}_{2}\right)_{4} \mathrm{NHCbz}$ & $\mathrm{CH}_{2} \mathrm{CH}_{3}$ & 6 & 31 & 61 & n.p. ${ }^{g}$ \\
\hline $\mathrm{CH}_{2} \mathrm{CH}_{2} \mathrm{SCH}_{3}$ & $\mathrm{CH}_{2} \mathrm{CH}_{3}$ & 7 & 40 & 57 & 78 \\
\hline $\mathrm{CH}\left(\mathrm{CH}_{3}\right) \mathrm{CH}_{2} \mathrm{CH}_{3}$ & $\mathrm{CH}_{2} \mathrm{CH}_{3}$ & 8 & 67 & 58 & 84 \\
\hline $\mathrm{CH}_{2} \mathrm{O}^{t} \mathrm{Bu}$ & $\mathrm{CH}_{2} \mathrm{CH}_{3}$ & 9 & 51 & 64 & 98 \\
\hline $\mathrm{CH}_{2} \mathrm{SCH}_{2} \mathrm{Ph}$ & $\mathrm{CH}_{2} \mathrm{CH}_{3}$ & 10 & 38 & 50 & 61 \\
\hline $\mathrm{CH}_{3} / \mathrm{CH}_{3}{ }^{i}$ & $\mathrm{CH}_{2} \mathrm{CH}_{3}$ & 11 & 61 & 62 & 79 \\
\hline $\mathrm{Ph}$ & $\mathrm{CH}_{2} \mathrm{CH}_{3}$ & 12 & 34 & 40 & 35 \\
\hline $\mathrm{CH}_{2} \mathrm{Ph}$ & $\mathrm{CH}_{2} \mathrm{CH}=\mathrm{CH}_{2}$ & 13 & 75 & n.p..$^{g}$ & n.p..$^{g}$ \\
\hline $\mathrm{CH}_{2} \mathrm{CH}\left(\mathrm{CH}_{3}\right)_{2}$ & $\mathrm{CH}_{2} \mathrm{CH}=\mathrm{CH}_{2}$ & 14 & 57 & 58 & n.p. ${ }^{g}$ \\
\hline $\mathrm{CH}\left(\mathrm{CH}_{3}\right) \mathrm{O}^{t} \mathrm{Bu}$ & $\mathrm{CH}_{2} \mathrm{CH}=\mathrm{CH}_{2}$ & 15 & 51 & 66 & n.p. ${ }^{g}$ \\
\hline $\mathrm{CH}_{3} / \mathrm{CH}_{3}{ }^{i}$ & $\mathrm{CH}_{2} \mathrm{CH}=\mathrm{CH}_{2}$ & 16 & 46 & 65 & n.p..$^{g}$ \\
\hline $\mathrm{Ph} / \mathrm{Ph}^{i}$ & $\mathrm{CH}_{2} \mathrm{CH}=\mathrm{CH}_{2}$ & 17 & 25 & n.p..$^{g}$ & n.p..$^{g}$ \\
\hline $\mathrm{CH}_{2} \mathrm{Ph}$ & $\mathrm{CH}_{2} \mathrm{Ph}$ & 18 & 70 & n.p..$^{g}$ & 85 \\
\hline $\mathrm{CH}_{2} \mathrm{CH}\left(\mathrm{CH}_{3}\right)_{2}$ & $\mathrm{CH}_{2} \mathrm{Ph}$ & 19 & 38 & 74 & 67 \\
\hline $\mathrm{CH}_{2} \mathrm{Ph}$ & $\mathrm{Ph}$ & 20 & n.p..$^{g}$ & 0 & n.p. ${ }^{g}$ \\
\hline $\mathrm{CH}_{2} \mathrm{O}^{t} \mathrm{Bu}$ & $\mathrm{Ph}$ & 21 & n.p..$^{g}$ & n.p..$^{g}$ & 30 \\
\hline $\mathrm{CH}_{2} \mathrm{Ph}$ & $\mathrm{CH}\left(\mathrm{CH}_{3}\right)_{2}$ & 22 & n.p..$^{g}$ & n.p. ${ }^{g}$ & $0(93)^{j}$ \\
\hline $\mathrm{CH}_{2} \mathrm{Ph}\left(p-\mathrm{O}^{t} \mathrm{Bu}\right)$ & $\mathrm{CH}\left(\mathrm{CH}_{3}\right)_{2}$ & 23 & n.p. ${ }^{g}$ & 0 & n.p..$^{g}$ \\
\hline $\mathrm{CH}_{2} \mathrm{Ph}\left(p-\mathrm{O}^{t} \mathrm{Bu}\right)$ & c-Hex & 24 & n.p..$^{g}$ & $49^{k}$ & n.p. ${ }^{g}$ \\
\hline
\end{tabular}

${ }^{a}$ Isolated yields. ${ }^{b} \mathrm{~L}-\alpha$-Amino esters were used except when otherwise stated. ${ }^{c}$ Conditions: (step 1) $\alpha$-amino ester (1 equiv.) and CDI (1.3 equiv.) at $450 \mathrm{rpm}, 50$ balls $(5 \mathrm{~mm}$, stainless steel, $5 \mathrm{~mm} \varnothing)$ for 40 min, (step 2) $\mathrm{R}_{2} \mathrm{NH}_{2}$ (1.6 equiv.) and $\mathrm{K}_{2} \mathrm{CO}_{3}$ (3.6 equiv.) at $450 \mathrm{rpm}$ for 2 hours. ${ }^{d} \alpha$-Amino ester ( 1 equiv.) $\mathrm{R}_{2} \mathrm{NCO}$ (3.0 equiv.) and $\mathrm{K}_{2} \mathrm{CO}_{3}(3.0$ equiv.) at $30 \mathrm{~Hz}$ for 2 hours, 2 balls ( $5 \mathrm{~mm}$, stainless steel, $5 \mathrm{~mm} \varnothing$ ). ${ }^{e} \mathrm{NC}=$ not crystallized, $\mathrm{RC}=$ recrystallized. ${ }^{f}$ Residual metals were analyzed by ICP-MS (see Experimental part). ${ }^{g}$ Not performed. ${ }^{h}$ The reaction was performed adding PEG-2000-(OMe $)_{2}\left(455 \mathrm{mg} \mathrm{mmol}^{-1}\right.$ substrate). ${ }^{i}$ Quaternary $\alpha$-amino ester $\mathrm{HCl} \cdot \mathrm{H}$-Aib-OMe or $\mathrm{HCl} \cdot \mathrm{H}$ $\mathrm{Gly}(\mathrm{Ph})_{2}$-OMe were used. ${ }^{j}$ Yield reported within brackets is given for the ureido intermediate. ${ }^{k 1} \mathrm{H}$ NMR yield using $\mathrm{CH}_{2} \mathrm{Br}_{2}(20 \mu \mathrm{L})$ as internal reference. 
isopropylamine, or the less reactive and poorly nucleophilic aniline. These results suggested that the limiting step was the formation of the corresponding ureido intermediate (first step). Surprisingly, the yield of the reaction dropped with an $\alpha$-amino ester component other than phenylalanine. Presuming that the difference in crystalline structure was the reason for this drop in the yield, the starting amino methyl esters were recrystallized to remove potential impurities.

After recrystallization, most of the desired hydantoins were obtained in much better yields (except for compound 8) especially in the case of compounds $5,6,10,19$. It can be hypothesized that the crystalline state and the steric and electronic nature of side chains of starting $\alpha$-amino esters drive the mechanochemical reactivity. Indeed, similar side chains (compounds 2/5, 8/4 and 9/15) led to similar yields. Electronically rich $\alpha$-amino esters, such as phenylglycine or diphenylglycine showed a moderate reactivity (12 and 17 respectively), while sterically hindered quaternary aminoisobutyric (Aib) methyl ester showed, as previously observed, ${ }^{30,33}$ good reactivity in mechanochemical processes (11 and 16), leading straightforwardly to 3-allyl-5,5'-dimethylhydantoin (ADMH, Fig. 1) 16 with a satisfying yield.

Overall, the mechanochemical preparation of CDI-mediated 3,5-disubstituted hydantoins is an environmentally friendly approach. The products were readily obtained from an easy-tohandle procedure, using cheap and commercially available substrates and reactants, allowing versatility of substituents in both $\mathrm{C}-5$ and N-3 hydantoin ring positions. In most cases, the products were recovered by precipitation in water, the only sideproducts present in the reaction mixture being the non-toxic water-soluble imidazole, $\mathrm{CO}_{2}$ and inorganic salts. When precipitation of the expected compound was not possible, extraction with ethyl acetate and benign $10 \%$ aqueous citric acid $^{35}$ was performed.

Mechanochemical preparation of 3,5-disubstituted hydantoins was also investigated using alkyl or aryl isocyanates (Method A, Scheme 1), for the sake of comparison and to provide an alternative route when Method B led to moderate yields. By grinding the $\alpha$-amino ester, the isocyanate and the potassium carbonate, a cascade reaction sequence occurred, involving formation of the ureido derivative $\mathbf{A}$, followed by in situ cyclization into hydantoins, with high atom economy (Scheme 1). In the case of benzyl hydantoin 2, no difference was observed when changing the jar material (stainless steel or tungsten carbide) or under different mechanical stress provided by a vibrational (VBM) or planetary (PBM) ball-mill (see Table S1 in ESI $\dagger$ ). Vibrational ball-mill and stainless steel jars were used to prepare 3,5-disubstituted hydantoins, readily obtained in good to excellent yields, with generally improved results compared to the CDI-mediated Method B (Table 2).

It is worth noting here that isopropylisocyanate reacted smoothly with phenylalanine methyl ester, leading to the corresponding ureido derivative in high yield (93\%). Cyclization was not observed, probably hampered by the steric hindrance around the nitrogen atom.

The study was completed by measuring the concentration of residual metals after ball-milling in the stainless-steel jar for compound 4 (see Experimental section). The organic product contamination was far below the threshold level of permitted daily exposures and uptake for elemental impurities in human. Overall, the two methods are a valuable alternative to solution syntheses, providing new or already commercialized compounds (see Table S2 in ESI†).

Method A was effective to access 3-ethyl-5,5'-dimethyl hydantoin (EDMH) 11 in good yield (79\%), that was further transformed into the textile antimicrobial additive ${ }^{5}$ 1-chloro-3ethyl-5,5'-dimethylhydantoin (CEDMH) 25. A chlorination reaction using mechanochemistry - never described before was performed in the planetary ball-mill using the swimming pool safe chlorinating agent trichloroisocyanuric acid (TCCA), which furnished 25 in 34\% yield, similar to the synthesis in solution (Scheme 2). Better results were obtained when calcium hypochlorite was used: not only was compound 25 obtained in the very good yield of $87 \%$, but the crude product was cleaner, generating only calcium salts as waste. This chlorination approach is a valuable and more powerful alternative to the use of TCCA either in solution or by grinding and it was successfully applied (99\% yield) also to the preparation of compound $\mathbf{2 6}$, with high chemioselectivity, with the allyl moiety unreactive in these conditions (Scheme 2).

\section{Synthesis of 3-ethyl-5-phenyl hydantoin (ethotoin, 12)}

The preparation of ethotoin in solution is restricted to only two publications, ${ }^{36,37}$ involving either cyclization of 5-ethyl-2phenylhydantoic acid $^{36}$ or rearrangement of ethyl $N$-Boc-phenylglycinamide $^{37}$ (70\% and $60 \%$ yield respectively) under anhydrous conditions, both strongly acid-catalyzed conditions.

$\mathrm{N}$-3-alkylation of 5-phenylhydantoin, prepared by mechanochemistry following our previously described procedure, ${ }^{30}$ remained unsuccessful in ball-milling conditions, or neat under stirring, even with a large excess of alkyl halide. The $N$-alkylation (Method C) was improved when poly(ethylene) glycol (HOPEG-400-OH) was used as the reaction solvent (entry 1, Table 3): ethotoin 12 was obtained in a $40 \%$ yield, a similar result to the previous methods A and B.

Poly(ethylene) glycols are green solvents ${ }^{38}$ with low toxicity, finding applications in the biomedical field ${ }^{39}$ and catalysis. ${ }^{40}$ Very recently, their peculiar role was highlighted in metal-

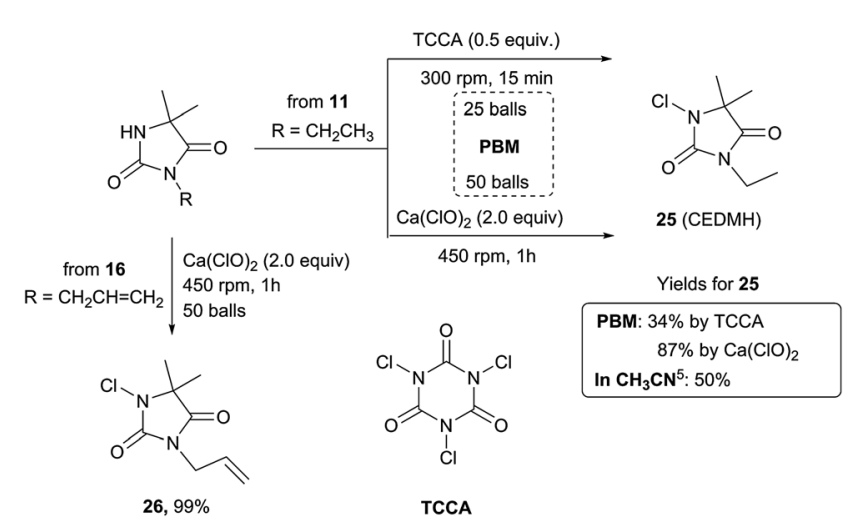

Scheme 2 Mechanochemical routes to CEDMH 25 and 26. 
Table 3 PEG-assisted grinding: three alternative synthetic routes to ethotoin 12

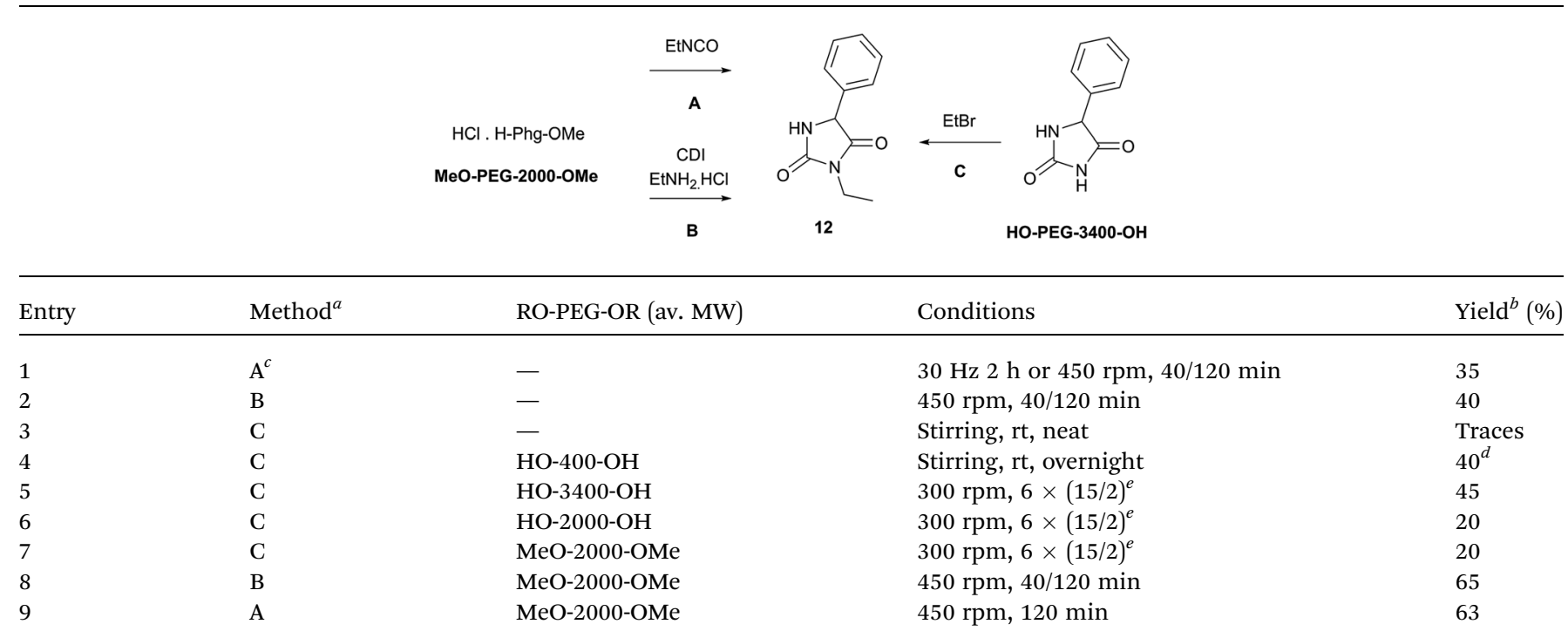

${ }^{a}$ L-Phenylglycine methyl ester was used; PEG (455 $\mathrm{mg} \mathrm{mmol}^{-1}$ substrate) was added in each experiment. ${ }^{b}$ Isolated yields. ${ }^{c}$ Both vibrational (VBM) and planetary (PBM) ball-mill were tested. ${ }^{d}$ Determined by NMR. ${ }^{e}$ The reaction medium was ground for 6 cycles of 15 min with 2 min pauses in between, with reverse rotation.

catalyzed processes in a ball-mill ${ }^{32}$ or by ultrasounds, ${ }^{\mathbf{4 1}}$ having in common similar activation effects, ${ }^{\mathbf{4 2}}$ or in Polymer-Assisted Grinding (POLAG) processes for co-crystal formation. ${ }^{31}$

Considering the preliminary result indicating that PEG polymer seemed to improve the efficiency of $\mathrm{N}$-alkylation, the conditions were transposed to a ball-milled reaction (Table 3 ). Using solid HO-PEG-3400-OH (entry 5) in the mechanochemical conditions produced ethotoin 12 in 45\% yield, compared with only traces when carried out under neat conditions (entry 3 ). The combination of mechanochemical forces and PEG matrix proved to be beneficial for $N$-alkylation when other approaches failed. Comparing several poly(ethylene) glycols (entries 5-7), it can be assumed that the length of the polymer might have an influence on the physical interactions of the system, more than its chemical composition. ${ }^{31}$ This suggests that the system would require a specific 'polymer catalyst' to be found, in agreement with the fact that mechanochemical forces can alter reaction pathways of synthetic polymers. ${ }^{43}$ In light of these results, $\mathrm{MeO}-$ PEG-2000-OMe was selected to grind the mixture (Table 3, entries 8 and 9) in the case of methods $\mathrm{A}$ and $\mathrm{B}$, to avoid potential side reactions of HO-PEG-3400-OH end terminal hydroxyl groups with ethyl isocyanate or CDI.

As presumed, the mechanochemical productivity in the presence of a PEG matrix was increased as the reactions were by far more efficient. 3-Ethyl-5-phenylhydantoin 12 was obtained in much higher yield from both methods (Table 3, entries 8 and 9) compared with grinding in the absence of additives (Tables 2 and 3 entries 2 and 3 ).

It was reported that solid dispersion of ethotoin 12 in PEG solvent displayed improved solubility and diffusion properties. ${ }^{44}$ At a molecular level, this was explained by the existence of hydrogen bonding $\mathrm{NH}^{\cdots} \mathrm{O}$ between the amide and the polyether chain. ${ }^{45}$ Similar interactions can be evoked with 5-phenyl hydantoin $^{30}$ (Method C) or ureido derivative A (Methods A and B). In this case, liquid-assisted grinding would be responsible for the enhanced mechanochemical productivity observed for all the methods. However, POLAG cannot be excluded, not only because the existence of interactions with PEG polymers are known to induce changes in the physical state of the system, ${ }^{\mathbf{4 5}}$ especially under mechanochemical stress, ${ }^{31}$ but also because PEG polymers act as a chelation matrix of potassium cations, as a result of its crown-ether-like effect. ${ }^{38}$ The direct consequence is that both reactivity and solubility of 'naked' $\mathrm{CO}_{3}{ }^{2-}$ counter ions under mechanochemical activation could be enhanced in the presence of PEG catalyst. Thus, two different effects acting in synergy and at different stages of the reaction mechanism could be responsible for the enhanced reactivity of the system in PEG: (i) improved solubility of reactants, reaction intermediates and final product; (ii) chelation effect of potassium cation (from $\mathrm{K}_{2} \mathrm{CO}_{3}$ ).

In view of these results, the PEG additive was also tested for preparation of compound $\mathbf{4}$ by using CDI- or isocyanate-based methods (Table 2). In the presence of MeO-PEG-2000-OMe, the yield was $70 \%$ when following Method B (27\%) - independently of the crystalline state of the starting material - and slightly improved when following Method A (90\%), however the recovery of the final pure product was more complicated. Instead of precipitation by water (when PEG was not used), liquid-liquid extraction and PEG-precipitation were needed, hampering the easiness of recovery and lessening the positive environmental impact of the methodology.

Compound 4 was analyzed to assess the chiral integrity for both A and B methods (Table 4). Chiral HPLC analyses (see ESI $\dagger$ ) for compound 4 showed complete loss of enantiopurity. 
Table 4 Assessment of chirality for PEG-assisted grinding to compound 4

\begin{tabular}{llllll}
\hline & \multicolumn{2}{l}{ Without PEG } & & \multicolumn{2}{l}{ With PEG $^{a}$} \\
\cline { 5 - 6 } Method & $\operatorname{er}^{b}(\%)$ & $\mathrm{ee}^{b}(\%)$ & & $\operatorname{er}^{b}(\%)$ & $\mathrm{ee}^{b}(\%)$ \\
\hline A & $53 / 47$ & 3 & $63 / 37$ & 26 \\
B & $53 / 47$ & 3 & $83 / 17$ & 66
\end{tabular}

${ }^{a}$ MeO-PEG-2000-OMe (455 $\mathrm{mg} \mathrm{mmol}^{-1}$ substrate) was added in each experiment. ${ }^{b}$ Reaction performed from L-H-Leu-OMe: er: $L / D$.

This might be due to the formation of 'high concentration' of potassium methanolate during cyclisation. However, the addition of MeO-PEG-2000-OMe proved to be beneficial, partially preserving the enantiopurity, probably because of the dilution effect of the medium. To the best of our knowledge, this is the first example showing that PEG-assisted grinding helped to retain optical purity to a certain extent. This unexpected behaviour deserves further investigations.

\section{Conclusions}

We described herein two mechanochemical routes to access diverse 3,5-disubstituted hydantoins from cheap and readily available $\alpha$-amino esters, either by reaction with isocyanates or by activation of the N-terminal position with CDI. The versatility of these procedures allowed us to prepare bactericide monomers or additives for polymer textiles such as 3-allyl-5,5'-dimethylhydantoin (ADMH) 16 and 1-chloro-3-ethyl-5,5'dimethylhydantoin (CEDMH) 25, obtained with highly increased yield compared with solution synthesis using $\mathrm{Ca}(\mathrm{ClO})_{2}$ as the chlorinating agent. Three novel and efficient procedures based on mechanochemistry and using polyoxygenated PEG solvents provided easy access to the anticonvulsant ethotoin 12 in good yields, with no use of strong base or acid and for which very few literature was available. Moreover, the use of a green solvent such as PEG has the advantage of being non-toxic, non-flammable and non-volatile, unlike solvents often used for LAG (ethyl acetate, nitromethane). The ball-mill technology afforded easily handling and mild reaction conditions and PEG solvents were applicable for all methods (A, $\mathrm{B}$ and $\mathrm{C}$ ) where grinding without an additive failed. However, further detailed studies are needed to elucidate the mechanistic aspects of this process when PEG is used. This would also shed light on its role in optical purity preservation during milling, never investigated before. It is worth noticing that the drug examples prepared here are either achiral or racemic, so the loss of chirality does not affect their preparation, even in the absence of the PEG additive.

The two mechanochemical methods herein described (Methods A and B) are a valuable alternative to solution synthesis to access to 3,5-dialkylhydantoins, but they were not suitable for the preparation of 3-aryl-5-alkyl hydantoin such as ethotoin 12, except when PEG was used. They have allowed the preparation of a library of hydantoins, some of which are already commercialized but whose synthesis has still not been divulged, but most have not been reported in the literature.

\section{Experimental section}

\section{Method A}

(Table 2, compounds 2, 4, 5, 7-12, 18-19 and 21) - Vibrational Ball Mill (VBM). The $\alpha$-amino methyl ester (1.0 equiv.), alkyl isocyanate (3.0 equiv.) and $\mathrm{K}_{2} \mathrm{CO}_{3}$ (3.0 equiv.) were ground in a vibrational ball-mill at $30 \mathrm{~Hz}$ for 2 hours. Distilled water was added to the reaction mixture and the desired compound was precipitated and filtered over sintered glass, or extracted with ethyl acetate. The organic layer was washed with $10 \%$ aq. citric acid $(\times 3)$ and brine $(\times 1)$, dried on $\mathrm{MgSO}_{4}$ and concentrated. Flash chromatography, normal or reverse phase, was performed on the crude sample.

Only for compound 12 (Table 3) - Planetary Ball Mill (PBM): in the case of PEG-assisted grinding the reaction was performed by adding MeO-PEG-2000-OMe (455 $\mathrm{mg} \mathrm{mmol}{ }^{-1}$ substrate), in a planetary ball-mill, at $450 \mathrm{rpm}$ for 2 hours using 50 balls ( 5 $\mathrm{mm}$ diameter). The compound was recovered by extraction with ethyl acetate after addition of distilled water to the reaction mixture. The organic layer was washed with $10 \%$ aq. citric acid and brine, dried over $\mathrm{MgSO}_{4}$ and concentrated. The compound was purified by flash chromatography (linear gradient of EtOAc in cyclohexane: $0-80 \%)$.

\section{Method B}

(Table 2, compounds 2, 4, 5-19 and 24) - Planetary Ball Mill (PBM). The $\alpha$-amino methyl ester (1.0 equiv.) and $1,1^{\prime}$-carbonylimidazole (CDI) (1.3 equiv.) were ground in a $12 \mathrm{~mL}$ stainless steel milling jar in a planetary ball-mill at $450 \mathrm{rpm}$ for 40 minutes using 50 balls ( $5 \mathrm{~mm}$ diameter). The amine (1.6 equiv.) and $\mathrm{K}_{2} \mathrm{CO}_{3}$ (3.6 equiv.) were added and the mixture was ground at $450 \mathrm{rpm}$ for two hours. Distilled water was added to the crude and the desired compound was precipitated and filtered over sintered glass, or extracted with ethyl acetate. The organic layer was washed with $10 \%$ aq. citric acid $(\times 3)$ and brine $(\times 1)$, dried on $\mathrm{MgSO}_{4}$ and concentrated. Flash chromatography, normal or reverse phase, was performed on the crude sample.

Only for compound 12 (Table 3): in the case of PEG-assisted grinding the reaction was performed adding MeO-PEG-2000OMe (455 mg mmol ${ }^{-1}$ substrate). The compound was recovered by extraction with ethyl acetate after addition of distilled water to the reaction mixture. The organic layer was washed with $10 \%$ aq. citric acid and brine, dried over $\mathrm{MgSO}_{4}$ and concentrated. The compound was purified by flash chromatography (linear gradient of EtOAc in cyclohexane: 0-80\%).

\section{Method C}

(Table 3, compound 12). 5-Phenylhydantoin ${ }^{30}$ (50 mg, 1.0 equiv.), ethyl bromide (106.0 $\mu \mathrm{L}, 5.0$ equiv.) and $\mathrm{K}_{2} \mathrm{CO}_{3}(40 \mathrm{mg}$ 1.0 equiv.) were milled with HO-PEG-3400-OH ( $455 \mathrm{mg} \mathrm{mmol}^{-1}$ substrate) in a planetary ball-mill at $300 \mathrm{rpm}$ for 6 cycles of 15 minutes with 2 minute pauses in between. Distilled water was added to the reaction mixture and the aqueous phase was 
extracted with ethyl acetate. The organic layer was washed $10 \%$ aq. citric acid $(\times 3)$ and brine $(\times 1)$, dried on $\mathrm{MgSO}_{4}$ and concentrated. Preparative TLC (cyclohexane: EtOAc $60: 40 \mathrm{v} / \mathrm{v}$ ) was performed on the crude sample.

3-Ethyl-5-benzylimidazolidine-2,4-dione 2 (Table 2). CAS [158500-83-5]. The reaction scale was: $0.20 \mathrm{mmol}$ (for VBM) or $1.16 \mathrm{mmol}$ (for PBM). The compound was obtained by precipitation in water (Method A: $32.6 \mathrm{mg}$, 75\% yield, Method B: 211.6 $\mathrm{mg}, 84 \%$ yield). White solid, $\mathrm{mp} 116-117{ }^{\circ} \mathrm{C}$; IR $\left(\mathrm{cm}^{-1}\right): 3278$ (NH), 3065, 2970, 2930, 1758 (C=O), 1693, 1605 (C=O), 1496, 1462, 1427, 1380, 1227, 1194, 1981, 1095, 1069, 1009, 919, 934, 859, 786, 765, 755, 748, 696, 679; ${ }^{1} \mathrm{H} \mathrm{NMR}\left(300 \mathrm{MHz}, \mathrm{CDCl}_{3}\right)^{46}$ $\delta$ (ppm): 7.32-7.18 (m, 5H, ArH), 5.87 (s, $1 \mathrm{H}, \mathrm{NH}), 4.23-4.20(\mathrm{~m}$, $1 \mathrm{H}, \mathrm{C}-5 / \mathrm{CH}), 3.51-3.43\left(\mathrm{~m}, 2 \mathrm{H}, \mathrm{CH}_{2}\right), 3.23(\mathrm{dd}, J=13.9$ and $J=$ 3.4, $1 \mathrm{H}, \mathrm{CH}_{2} / \mathrm{H}_{\mathrm{A}}$ ), 2.88 (dd, $J=13.9$ and $J=8.1,1 \mathrm{H}, \mathrm{CH}_{2} / \mathrm{H}_{\mathrm{B}}$ ), $1.06\left(\mathrm{t}, J=7.1,3 \mathrm{H}, \mathrm{CH}_{3}\right) ;{ }^{13} \mathrm{C} \mathrm{NMR}\left(300 \mathrm{MHz} \mathrm{CDCl}_{3}\right) \delta(\mathrm{ppm})$ : 172.9, 157.0, 135.1, 129.3, 128.8, 127.4, 58.2, 37.9, 33.5, 13.2; MS ESI-(+): $m / z 219[\mathrm{M}+\mathrm{H}]^{+}$.

ICP-MS data. Concentration of residual metal after ballmilling in the stainless steel jar. Quantity of sample analyzed: $50 \mathrm{mg}$.

\begin{tabular}{|c|c|c|c|c|c|c|}
\hline Method & $\begin{array}{c}\mathrm{Mn} \\
\mathrm{Cr}[\mathrm{ppb}][\mathrm{ppb}]\end{array}$ & $\mathrm{Fe}[\mathrm{ppb}]$ & $\begin{array}{l}\mathrm{Ni} \\
{[\mathrm{ppb}]}\end{array}$ & $\begin{array}{l}\mathrm{Cu} \\
{[\mathrm{ppb}]}\end{array}$ & $\begin{array}{l}\mathrm{Cd} \\
{[\mathrm{ppb}]}\end{array}$ & $\begin{array}{l}\mathrm{W} \\
{[\mathrm{ppb}]}\end{array}$ \\
\hline $\begin{array}{l}\mathbf{A} \\
(\mathrm{VBM})\end{array}$ & 28736.11871 .0 & 224714.1 & 1736.5 & 1047.7 & 61.2 & 3.9 \\
\hline $\begin{array}{l}\text { B } \\
(\mathrm{PBM})\end{array}$ & 38846.91561 .1 & 219276.2 & 889.4 & 2200.6 & 12.6 & 26.7 \\
\hline
\end{tabular}

3-Ethyl-5-isobutylimidazolidine-2,4-dione 4 (Table 2). The reaction scale was: $0.20 \mathrm{mmol}$ (for $\mathrm{VBM}$ ) or $1.05 \mathrm{mmol}$ (for PBM). The compound was obtained by precipitation in water (Method A: 30.4 mg, 83\% yield; Method B: $147.1 \mathrm{mg}$, 76\% yield). White solid, mp 116-117 ${ }^{\circ} \mathrm{C}$; IR $\left(\mathrm{cm}^{-1}\right)$ : 3226, $3098(\mathrm{NH}), 2962$, 2940, 2876, 1760 ( $\mathrm{C}=\mathrm{O}), 1697$ ( $\mathrm{C}=\mathrm{O}), 1450,1423,1350,1314$, 1256, 1216, 1147, 1092, 1007, 873, 841, 783, 764, 709; ${ }^{1} \mathrm{H}$ NMR $\left(300 \mathrm{MHz}_{\mathrm{CDCl}}\right) \delta(\mathrm{ppm}): 5.74(\mathrm{~s}, 1 \mathrm{H}, \mathrm{NH}), 4.01(\mathrm{~m}, 1 \mathrm{H}, \mathrm{C}-5 /$ $\mathrm{CH}), 3.55$ (q, $\left.J=7.1,2 \mathrm{H}, \mathrm{CH}_{2}\right), 1.79\left(\mathrm{~m}, 2 \mathrm{H}, \mathrm{CH}_{2}\right), 1.51(\mathrm{~m}$, $1 \mathrm{H}, \mathrm{CH}), 1.21\left(\mathrm{t}, J=7.2,3 \mathrm{H}, \mathrm{CH}_{3}\right), 0.97\left(\mathrm{~m}, 6 \mathrm{H}, \mathrm{CH}_{3}\right) ;{ }^{13} \mathrm{C} \mathrm{NMR}$ $\left(300 \mathrm{MHz} \mathrm{CDCl}_{3}\right) \delta(\mathrm{ppm}): 174.4,157.6,55.9,41.0,33.7,25.4$, 23.2, 21.8, 13.5; MS ESI- $(+): m / z 185[\mathrm{M}+\mathrm{H}]^{+}$; HRMS ESI- $(+)$: calcd for $\mathrm{C}_{9} \mathrm{H}_{17} \mathrm{~N}_{2} \mathrm{O}_{2}[\mathrm{M}+\mathrm{H}]^{+}$185.1290, found 185.1292.

3-Ethyl-5-[(4-tert-butoxy)-phenylmethyl]-imidazolidine-2,4dione 5 (Table 2). The reaction scale was: $0.22 \mathrm{mmol}$ (for VBM) or $0.95 \mathrm{mmol}$ (for PBM). The compound was obtained by precipitation in water (Method A: $225.1 \mathrm{mg}, 82 \%$ yield; Method B: $52.0 \mathrm{mg}, 82 \%$ yield). White solid, $\mathrm{mp} 123-125{ }^{\circ} \mathrm{C}$; IR $\left(\mathrm{cm}^{-1}\right)$ : $3258(\mathrm{NH}), 2971,2933,1761(\mathrm{C}=\mathrm{O}), 1698(\mathrm{C}=\mathrm{O}), 1609,1507$, 1426, 1353, $1257\left(\mathrm{C}\left(\mathrm{CH}_{3}\right)_{3}\right), 1222\left(\mathrm{C}\left(\mathrm{CH}_{3}\right)_{3}\right), 1179,1161,1104$, $897,877,840,761,707 ;{ }^{1} \mathrm{H}$ NMR $\left(300 \mathrm{MHz}, \mathrm{CDCl}_{3}\right) \delta(\mathrm{ppm}): 7.08$ $\left(\mathrm{d}, J=8.2,2 \mathrm{H}, \mathrm{ArH}^{3,5}\right), 6.93\left(\mathrm{~d}, J=8.2,2 \mathrm{H}, \mathrm{ArH}^{2,6}\right), 5.39(\mathrm{~s}, 1 \mathrm{H}$, $\mathrm{NH}), 4.19(\mathrm{~m}, 1 \mathrm{H}, \mathrm{C}-5 / \mathrm{CH}), 3.48\left(\mathrm{~m}, 2 \mathrm{H}, \mathrm{CH}_{2}\right), 3.20$ (dd, $J=13.9$ and $\left.J=3.3,1 \mathrm{H}, \mathrm{CH}_{2} / \mathrm{H}_{\mathrm{A}}\right), 2.83\left(\mathrm{dd}, J=13.8\right.$ and $J=8.2,1 \mathrm{H}, \mathrm{CH}_{2} /$ $\left.\mathrm{H}_{\mathrm{B}}\right), 1.32\left(\mathrm{~s}, 9 \mathrm{H}, \mathrm{OC}\left(\mathrm{CH}_{3}\right)_{3}\right), 1.08\left(\mathrm{t}, J=7.1,3 \mathrm{H}, \mathrm{CH}_{3}\right) ;{ }^{13} \mathrm{C} \mathrm{NMR}$ $\left(300 \mathrm{MHz}, \mathrm{CDCl}_{3}\right) \delta$ (ppm): 173.1, 157.0, 155.0, 130.0, 124.6, 78.8, 58.4, 37.4, 33.7, 29.0, 13.4; MS ESI-(+): $m / z 291[\mathrm{M}+\mathrm{H}]^{+}$,
$235\left[\left(\mathrm{M}-{ }^{t} \mathrm{Bu}\right)+\mathrm{H}\right]^{+}$; HRMS ESI- $(+)$: calcd for $\mathrm{C}_{16} \mathrm{H}_{22} \mathrm{~N}_{2} \mathrm{O}_{3}[\mathrm{M}+$ $\mathrm{Na}]^{+}$313.1528, found 313.1526.

Benzyl 4-(1-ethyl-2,5-dioxoimidazolidin-4-yl)-butylcarbamate 6 (Table 2). The reaction scale was: $0.86 \mathrm{mmol}$ (for PBM). The compound was purified by flash chromatography (linear gradient of EtOAc in cyclohexane: 0-80\%); (Method B: $173.8 \mathrm{mg}$, $61 \%$ yield). White solid, mp 92-94 ${ }^{\circ} \mathrm{C}$; IR $\left(\mathrm{cm}^{-1}\right): 3309,3221$ (NH), 3100, 2926, 2860, $1765(\mathrm{C}=\mathrm{O}), 1686(\mathrm{C}=\mathrm{O}), 1540,1463$, 1436, 1272, 1141, 1108, 1026, 796, 765, 691; ${ }^{1} \mathrm{H}$ NMR $(300 \mathrm{MHz}$, DMSO- $\left.d_{6}\right) \delta(\mathrm{ppm}): 8.19(\mathrm{~s}, 1 \mathrm{H}, \mathrm{NH}), 7.36-7.23(\mathrm{~m}, 6 \mathrm{H}, \mathrm{ArH}), 5.00$ (s, 2H, $\left.\mathrm{OCH}_{2}\right), 4.02-3.99(\mathrm{~m}, 1 \mathrm{H}, \mathrm{C}-5 / \mathrm{CH}), 3.38-3.34(\mathrm{~m}, 2 \mathrm{H}$, $\left.\mathrm{CH}_{2}\right), 2.96\left(\mathrm{q}, J=6.0,2 \mathrm{H}, \mathrm{CH}_{2}\right), 1.67-1.23\left(\mathrm{~m}, 6 \mathrm{H},\left(\mathrm{CH}_{2}\right)_{3}\right), 1.05(\mathrm{t}$, $\left.J=7.1,3 \mathrm{H}, \mathrm{CH}_{3}\right) ;{ }^{13} \mathrm{C}$ NMR $\left(300 \mathrm{MHz}, \mathrm{DMSO}-d_{6}\right) \delta(\mathrm{ppm}): 174.1$, 156.7, 156.1, 137.3, 128.4, 127.7, 65.1, 56.1, 32.5, 30.9, 21.3, 13.3; MS ESI-(+): $m / z 334[\mathrm{M}+\mathrm{H}]^{+}, 290,226,356[\mathrm{M}+\mathrm{Na}]^{+}$. HRMS ESI$(+)$ : calcd for $\mathrm{C}_{17} \mathrm{H}_{23} \mathrm{~N}_{3} \mathrm{O}_{4}[\mathrm{M}+\mathrm{H}]^{+} 334.1767$, found 334.1765.

3-Ethyl-5-[2-(methylthio)ethyl]imidazolidine-2,4-dione 7 (Table 2). CAS [1218137-72-4]. The reaction scale was: 0.20 $\mathrm{mmol}$ (for VBM) or $1.03 \mathrm{mmol}$ (for PBM). The compound was purified by flash chromatography (linear gradient of EtOAc in cyclohexane: $0-80 \%$ ); (Method A: $31.6 \mathrm{mg}$, 78\% yield, Method B: $118.3 \mathrm{mg}, 57 \%$ yield). Pale yellow solid, $\mathrm{mp} 82-84{ }^{\circ} \mathrm{C}$; IR $\left(\mathrm{cm}^{-1}\right)$ : 3447, $3295(\mathrm{NH}), 2981,2933,1759(\mathrm{C}=\mathrm{O}), 1684(\mathrm{C}=\mathrm{O}), 455$, 1422, 1353, 1288, 1218, 1174, 1106, 1007, 999, 967; 833, 765, $708 ;{ }^{1} \mathrm{H}$ NMR $\left(300 \mathrm{MHz}, \mathrm{CDCl}_{3}\right) \delta(\mathrm{ppm}): 6.01(\mathrm{~s}, 1 \mathrm{H}, \mathrm{NH}), 4.14$ (m, $1 \mathrm{H}, \mathrm{C}-5 / \mathrm{CH}), 3.56$ (q, $\left.J=6.8,2 \mathrm{H}, \mathrm{CH}_{2}\right), 2.64\left(\mathrm{~m}, 2 \mathrm{H}, \mathrm{CH}_{2}\right)$, 2.29-2.20 (m, $\left.1 \mathrm{H}, \mathrm{CH}_{2} / \mathrm{H}_{\mathrm{A}}\right), 2.11\left(\mathrm{~s}, 3 \mathrm{H}, \mathrm{SCH}_{3}\right), 2.00-1.88(\mathrm{~m}, 1 \mathrm{H}$, $\left.\mathrm{CH}_{2} / \mathrm{H}_{\mathrm{B}}\right), 1.21$ (t, $\left.J=6.8,3 \mathrm{H}, \mathrm{CH}_{3}\right) ;{ }^{13} \mathrm{C} \mathrm{NMR} \mathrm{(300} \mathrm{MHz}, \mathrm{CDCl}_{3}$ ) $\delta$ (ppm): 173.7, 157.4, 56.6, 33.8, 30.7, 30.5, 15.4, 13.5; MS ESI$(+): m / z 203[\mathrm{M}+\mathrm{H}]^{+}, 174$, 155. HRMS ESI- $(+)$ : calcd for $\mathrm{C}_{8} \mathrm{H}_{14} \mathrm{~N}_{2} \mathrm{O}_{2} \mathrm{~S}[\mathrm{M}+\mathrm{H}]^{+}$203.0854, found 203.0849.

3-Ethyl-5-(sec-butyl)-imidazolidine-2,4-dione 8 (Table 2). CAS [1218012-31-7]. The reaction scale was: $0.20 \mathrm{mmol}$ (for VBM) or $1.05 \mathrm{mmol}$ (for PBM). The compound was obtained by precipitation in water (Method A: $30.8 \mathrm{mg}$, 84\% yield; Method B: 112.4 $\mathrm{mg}, 58 \%$ yield). Colourless oil. IR $\left(\mathrm{cm}^{-1}\right): 3243(\mathrm{NH}), 2965,2877$, $1765(\mathrm{C}=\mathrm{O}), 1693$ ( $\mathrm{C}=\mathrm{O}), 1451,1425,1350,1214,1121,1003$, 956, 903, 764, 708; ${ }^{1} \mathrm{H}$ NMR (300 MHz, DMSO- $\left.d_{6}\right) \delta(\mathrm{ppm}): 8.15$ (s, 1H, NH), 4.01 (m, 1H, C-5/CH), 3.39-3.35 (m, 2H, $\left.\mathrm{CH}_{2}\right), 1.80-$ $1.76(\mathrm{~m}, 1 \mathrm{H}, \mathrm{CH}), 1.37-1.11\left(\mathrm{~m}, 1 \mathrm{H}, \mathrm{CH}_{2} / \mathrm{H}_{\mathrm{A}}\right), 1.04(\mathrm{t}, J=7.1,3 \mathrm{H}$, $\left.\mathrm{CH}_{3}\right), 0.90-0.68\left(\mathrm{~m}, 10 \mathrm{H}, \mathrm{CH}_{3}\right.$ and $\left.\mathrm{CH}_{2} / \mathrm{H}_{\mathrm{B}}\right) ;{ }^{13} \mathrm{C} \mathrm{NMR}(300 \mathrm{MHz}$, DMSO- $\left.d_{6}\right) \delta(\mathrm{ppm})$ (1:1 mixture of diastereoisomers): 173.9, 173.5, 157.2, 156.9, 60.8, 59.6, 38.7, 36.4, 36.1, 32.4, 25.5, 23.3, 14.9, 13.3, 12.9, 11.6; MS ESI- $(+): m / z 185[\mathrm{M}+\mathrm{H}]^{+}$; HRMS ESI$(+)$ : calcd for $\mathrm{C}_{9} \mathrm{H}_{17} \mathrm{~N}_{2} \mathrm{O}_{2}[\mathrm{M}+\mathrm{H}]^{+}$185.1290, found 185.1288.

3-Ethyl-5-(tert-butoxymethyl)-imidazolidine-2,4-dione 9 (Table 2). The reaction scale was: $0.20 \mathrm{mmol}$ (for VBM) or 1.02 mmol (for PBM). The compound was purified by flash chromatography (linear gradient of EtOAc in cyclohexane: 080\%); (Method A: $42.1 \mathrm{mg}$, 98\% yield; Method B: $139.0 \mathrm{mg}$, $64 \%$ yield). White solid, mp 119-121 ${ }^{\circ} \mathrm{C}$; IR $\left(\mathrm{cm}^{-1}\right): 3304$ $(\mathrm{NH}), 2971,2933,1764(\mathrm{C}=\mathrm{O}), 1698(\mathrm{C}=\mathrm{O}), 1460,1430,1359$, $1234\left(\mathrm{C}\left(\mathrm{CH}_{3}\right)_{3}\right), 1213\left(\mathrm{C}\left(\mathrm{CH}_{3}\right)_{3}\right), 1195,1119,1100,1069,887$, 810, 755, 707, 676; $\left.{ }^{1} \mathrm{H} \mathrm{NMR} \mathrm{(300} \mathrm{MHz,} \mathrm{CDCl}_{3}\right) \delta(\mathrm{ppm}): 5.74(\mathrm{~s}$, $1 \mathrm{H}, \mathrm{NH}), 4.10(\mathrm{dd}, J=7.5$ and $J=2.9,1 \mathrm{H}, \mathrm{C}-5 / \mathrm{CH}), 3.74(\mathrm{dd}, J$ $=9.2$ and $\left.J=3.0,1 \mathrm{H}, \mathrm{CH}_{2} / \mathrm{H}_{\mathrm{A}}\right), 3.59-3.44\left(\mathrm{~m}, 3 \mathrm{H}, \mathrm{CH}_{2} / \mathrm{H}_{\mathrm{B}}\right.$ and $\left.\mathrm{CH}_{2}\right), 1.23-1.17\left(\mathrm{~m}, 13 \mathrm{H}, \mathrm{CH}_{3}\right.$ and $\left.\mathrm{OC}\left(\mathrm{CH}_{3}\right)_{3}\right) ;{ }^{13} \mathrm{C}$ NMR (300 
$\left.\mathrm{MHz}, \mathrm{CDCl}_{3}\right) \delta(\mathrm{ppm}): 171.9,157.5,74.1,62.0,58.1,33.8,27.5$, 13.5; MS ESI-(+): $m / z 185[\mathrm{M}+\mathrm{H}]^{+}$; HRMS ESI-(+): calcd for $\mathrm{C}_{8} \mathrm{H}_{18} \mathrm{~N}_{3} \mathrm{O}_{3}[\mathrm{M}+\mathrm{H}]^{+}$215.0668, found 215.0670.

5-(Benzylthiomethyl)-3-ethylimidazolidine-2,4-dione 10 (Table 2). The reaction scale was: $0.18 \mathrm{mmol}$ (for VBM) or 0.97 mmol (for PBM). No further purification after work-up was needed. (Method A: $28.9 \mathrm{mg}, 61 \%$ yield; Method B: $128.0 \mathrm{mg}$, $50 \%$ yield). White solid, mp 96-98 ${ }^{\circ} \mathrm{C}$; IR $\left(\mathrm{cm}^{-1}\right): 3221(\mathrm{NH})$ 3098, 2968, 2917, 1757 ( $\mathrm{C}=\mathrm{O}), 1700$ ( $\mathrm{C}=\mathrm{O}), 1451,1405,1346$, 1237, 1216, 1115, 999, 878, 813, 776, 730, 693; ${ }^{1} \mathrm{H}$ NMR $(300$ MHz, DMSO- $\left.d_{6}\right) \delta(\mathrm{ppm}): 8.29(\mathrm{~s}, 1 \mathrm{H}, \mathrm{NH}), 7.31-7.24(\mathrm{~m}, 5 \mathrm{H}$, $\mathrm{ArH}), 4.35$ ( $\left.\mathrm{s}_{\text {broad }}, 1 \mathrm{H}, \mathrm{C}-5 / \mathrm{CH}\right), 3.77$ (s, 2H, $\mathrm{SCH}_{2}$ ), 3.40-3.37 (m, $\left.2 \mathrm{H}, \mathrm{CH}_{2}\right), 2.76\left(\mathrm{~m}, 2 \mathrm{H}, \mathrm{CH}_{2}\right), 1.08\left(\mathrm{t}, J=7.1,3 \mathrm{H}, \mathrm{CH}_{3}\right) ;{ }^{13} \mathrm{C} \mathrm{NMR}$ $\left(300 \mathrm{MHz}, \mathrm{DMSO}-d_{6}\right) \delta(\mathrm{ppm}): 172.9,156.8,138.2,128.9,128.4$, 127.0, 56.3, 36.0, 32.7, 32.1, 13.3; MS ESI-(+): $m / z 265[\mathrm{M}+\mathrm{H}]^{+}$. HRMS ESI- $(+)$ : calcd for $\mathrm{C}_{13} \mathrm{H}_{16} \mathrm{~N}_{2} \mathrm{O}_{2} \mathrm{~S}[\mathrm{M}+\mathrm{H}]^{+}$265.1011, found 265.1007.

3-Ethyl-5,5'-dimethyl-2,4-imidazolidinedione 11 (Table 2). CAS [37021-15-1]. The reaction scale was: $0.21 \mathrm{mmol}$ (for VBM) or $1.08 \mathrm{mmol}$ (for PBM). No further purification after work-up was needed. (Method A: $25.8 \mathrm{mg}$, 79\% yield; Method B: 104.5 mg, $62 \%$ yield). White solid, mp $72-74{ }^{\circ} \mathrm{C}$ (lit. $\left.{ }^{5} 96^{\circ} \mathrm{C}\right)$; IR $\left(\mathrm{cm}^{-1}\right)$ : $3212(\mathrm{NH})$, 3099, 2980, 2937, $1766(\mathrm{C}=\mathrm{O}), 1700(\mathrm{C}=\mathrm{O}), 1449$, $1420,1349,1285,1204,1180,1094,1067,936,879,751,705 ;{ }^{1} \mathrm{H}$ NMR (300 MHz, DMSO- $\left.d_{6}\right) \delta$ (ppm): 8.22 (s, $\left.1 \mathrm{H}, \mathrm{NH}\right), 3.39-3.32$ $\left(\mathrm{m}, 2 \mathrm{H}, \mathrm{CH}_{2}\right), 1.26\left(\mathrm{~s}, 6 \mathrm{H}, \mathrm{CH}_{3}\right), 1.06\left(\mathrm{t}, J=7.1,3 \mathrm{H}, \mathrm{CH}_{3}\right) ;{ }^{13} \mathrm{C}$ NMR (300 MHz, DMSO- $\left.d_{6}\right) \delta(\mathrm{ppm}): 177.6,155.7,58.0,33.0$, 25.0, 13.7; MS ESI-(+): $m / z$ 157.0 [M + H $]^{+}$; HRMS ESI-(+): calcd for $\mathrm{C}_{7} \mathrm{H}_{12} \mathrm{~N}_{2} \mathrm{O}_{2}[\mathrm{M}+\mathrm{H}]^{+}$157.0977, found 157.0978.

3-Ethyl-5-phenyl-2,4-imidazolidinedione 12 (Table 3). CAS $[86-35-1]^{48}$. The reaction scale was: $1.24 \mathrm{mmol}$ (for Method A) or $0.92 \mathrm{mmol}$ (for Method B). No further purification after work-up was needed. Yields given are referred to PEG-assisted grinding. (Method A: $160.5 \mathrm{mg}, 63 \%$; Method B: $121.8 \mathrm{mg}$, 65\% yield; Method C: $25.8 \mathrm{mg}, 45 \%$ ). White solid, mp 86-88 ${ }^{\circ} \mathrm{C}$ (the synthesis was previously published but melting point ${ }^{36,37}$ was not reported); IR $\left(\mathrm{cm}^{-1}\right)$ : $3320(\mathrm{NH}), 2982,2945,1762(\mathrm{C}=\mathrm{O})$, $1691(\mathrm{C}=\mathrm{O})$; 1454, 1427, 1340, 1288, 1211, 1179, 1080, 1002, 824, 760, 701; ${ }^{1} \mathrm{H}$ NMR (300 MHz, DMSO- $\left.d_{6}\right) \delta(\mathrm{ppm}): 8.68(\mathrm{~s}, 1 \mathrm{H}$, $\mathrm{NH}), 7.43-7.31$ (m, 5H, ArH), 5.19 (s, 1H, C-5/CH), 3.40 (qd, $J=$ 7.0 and $\left.J=1.7,2 \mathrm{H}, \mathrm{CH}_{2}\right), 1.08\left(\mathrm{t}, J=7.1,3 \mathrm{H}, \mathrm{CH}_{3}\right) ;{ }^{13} \mathrm{C} \mathrm{NMR}$ $\left(300 \mathrm{MHz}, \mathrm{DMSO}-d_{6}\right) \delta(\mathrm{ppm}): 172.0,157.7,134.5,129.3,129.2$, 126.6, 60.8, 34.0, 31.0, 13.5; MS ESI- $(+): m / z 205[\mathrm{M}+\mathrm{H}]^{+}$.

3-Allyl-5-benzyl-2,4-imidazolidinedione 13 (Table 2). CAS [160448-61-3]. The reaction scale was: $1.16 \mathrm{mmol}$ (for PBM). The compound was obtained by precipitation in water; (Method B: $197.9 \mathrm{mg}, 75 \%$ yield). White solid, $\mathrm{mp} 116-118^{\circ} \mathrm{C}$; IR $\left(\mathrm{cm}^{-1}\right)$ : 3447, $3341(\mathrm{NH})$, 3031, 2927, 1767 (C=O), 1698 (C=O), 1496, 1450, 1418, 1359, 1312, 1254, 1207, 1119, 1000, 937, 915, 752, 738, 702, 669, 654; ${ }^{1} \mathrm{H}$ NMR (300 MHz, DMSO- $\left.d_{6}\right) \delta$ (ppm): 8.28 (s, 1H, NH), 7.26-7.15 (m, 5H, ArH), $5.48(\mathrm{td}, J=10.8$ and $J=$ $5.2,1 \mathrm{H}$, CHallyl), $4.86\left(\mathrm{~d}, J=10.3,1 \mathrm{H}, \mathrm{CH}_{2}\right.$ allyl $\left./ \mathrm{H}_{c i s}\right), 4.54(\mathrm{~d}, J=$ 17.3, $1 \mathrm{H}, \mathrm{CH}_{2}$ allyl/ $\mathrm{H}_{\text {trans }}$ ), 4.44-4.42 (m, 1H, C-5/CH), 3.84-3.69 $\left(\mathrm{m}, 2 \mathrm{H}, \mathrm{CH}_{2}\right), 2.98$ (d, $\left.J=3.3,2 \mathrm{H}, \mathrm{CH}_{2}\right) ;{ }^{13} \mathrm{C} \mathrm{NMR}(300 \mathrm{MHz}$, DMSO- $\left.d_{6}\right) \delta$ (ppm): 173.0, 156.1, 135.2, 131.8, 129.8, 128.1, 126.7, 115.6, 57.1, 36.3; MS ESI-(+): $m / z 231$ [M + H] $]^{+}$; HRMS ESI$(+)$ : calcd for $\mathrm{C}_{13} \mathrm{H}_{14} \mathrm{~N}_{2} \mathrm{O}_{2}[\mathrm{M}+\mathrm{H}]^{+}$231.1134, found 231.1134.
3-Allyl-5-isobutylimidazolidine-2,4-dione 14 (Table 2). CAS [51112-67-5]. The reaction scale was: $1.19 \mathrm{mmol}$ (for PBM). The compound was purified by flash chromatography (linear gradient of EtOAc in cyclohexane: 0-80\%); (Method B: $110.5 \mathrm{mg}$, $58 \%$ yield). White solid, mp 95-97 ${ }^{\circ} \mathrm{C}$; IR $\left(\mathrm{cm}^{-1}\right): 3221(\mathrm{NH})$, 3099, 2955, 2871, 1676 ( $\mathrm{C}=\mathrm{O}), 1708$ (C=O) 1647, 1451, 1410, 1371, 1359, 1336, 1207, 1155, 996, 929, 875, 731, 693, 661; ${ }^{1} \mathrm{H}$ NMR (300 MHz, $\left.\mathrm{CDCl}_{3}\right) \delta(\mathrm{ppm}): 5.85-5.76(\mathrm{~m}, 2 \mathrm{H}, \mathrm{NH}$ and CHallyl), 5.30-5.18 (m, 2H, $\mathrm{CH}_{2}$ allyl), 4.11-4.05 (m, 3H, C-5/CH and $\left.\mathrm{CH}_{2}\right), 1.81-1.79\left(\mathrm{~m}, 2 \mathrm{H}, \mathrm{CH}_{2}\right), 1.60-1.42(\mathrm{~m}, 1 \mathrm{H}, \mathrm{CH}), 0.98$ $\left(\mathrm{t}, J=4.4,3 \mathrm{H}, \mathrm{CH}_{3}\right) ;{ }^{13} \mathrm{C} \mathrm{NMR}\left(300 \mathrm{MHz} \mathrm{CDCl}_{3}\right) \delta(\mathrm{ppm}): 174.2$, 157.3, 131.2, 118.1, 56.0, 41.1, 40.7, 25.4, 23.2, 21.8; MS ESI-(+): $m / z 197[\mathrm{M}+\mathrm{H}]^{+}, 169.0$; HRMS ESI-(+): calcd for $\mathrm{C}_{10} \mathrm{H}_{16} \mathrm{~N}_{2} \mathrm{O}_{2}[\mathrm{M}$ $+\mathrm{H}]^{+}$197.1290, found 197.1292.

3-Allyl-5-[1-(tert-butoxy)-ethyl]-imidazolidine-2,4-dione 15 (Table 2). The reaction scale was: $1.14 \mathrm{mmol}$ (for PBM). The compound was purified by flash chromatography (linear gradient of EtOAc in cyclohexane: 0-80\%); (Method B: $181.9 \mathrm{mg}$, $66 \%$ yield). White solid, mp 51-53 ${ }^{\circ} \mathrm{C}$; IR $\left(\mathrm{cm}^{-1}\right): 3300(\mathrm{NH})$, 2975, 2935, 1753 (C=O), 1697 ( $\mathrm{C}=\mathrm{O}), 1648$, 1556, 1451 $\left(\mathrm{C}\left(\mathrm{CH}_{3}\right)_{3}\right), 1415\left(\mathrm{C}\left(\mathrm{CH}_{3}\right)_{3}\right), 1363,1191,1123,1078,969,923,771$, 734; ${ }^{1} \mathrm{H}$ NMR $\left(300 \mathrm{MHz}\right.$, DMSO- $\left.d_{6}\right) \delta(\mathrm{ppm})$ (3:1 mixture of diastereoisomers): $8.19(2 \times \mathrm{s}, 1 \mathrm{H}, \mathrm{NH}), 5.80-5.67(\mathrm{~m}, 1 \mathrm{H}$, CHallyl), 5.14-5.05 (m, 2H, $\mathrm{CH}_{2}$ allyl), 4.03-3.90 (m, 4H, C-5/CH, OCH and $\left.\mathrm{CH}_{2}\right), 1.19-1.05\left(\mathrm{~m}, 12 \mathrm{H}, \mathrm{CH}_{3}\right.$ and $\left.\mathrm{OC}\left(\mathrm{CH}_{3}\right)\right) ;{ }^{13} \mathrm{C} \mathrm{NMR}$ $\left(300 \mathrm{MHz}, \mathrm{DMSO}-d_{6}\right) \delta(\mathrm{ppm})$ (3:1 mixture of diastereoisomers): 172.8, 172.2, 157.4, 157.1, 132.8, 132.7, 121.7, 116.6, 116.3, 74.2, 73.8, 67.6, 66.1, 63.2, 62.0, 28.8, 28.6, 20.9, 18.5; MS ESI-(+): $m / z 241[\mathrm{M}+\mathrm{H}]^{+}, 185.0$; HRMS ESI- $(+)$ : calcd for $\mathrm{C}_{12} \mathrm{H}_{20} \mathrm{~N}_{2} \mathrm{O}_{3}[\mathrm{M}+\mathrm{H}]^{+}$241.1552, found 241.1554.

3-Allyl-5,5-dimethylimidazolidine-2,4-dione 16 (Table 2). CAS [158500-83-5]. The reaction scale was: $1.23 \mathrm{mmol}$ (for PBM). The compound was purified by flash chromatography (linear gradient of EtOAc in cyclohexane: 0-80\%); (Method B: $134.3 \mathrm{mg}$, $65 \%$ yield). Colourless oil. IR ( $\left.\mathrm{cm}^{-1}\right): 3460,3326(\mathrm{NH}), 3090,2979$, 2937, 2879, 1760 ( $\mathrm{C}=\mathrm{O}), 1690(\mathrm{C}=\mathrm{O}), 1645,1527,1444,1393$, 1329, 1265, 1178, 1015, 972, 916, 874, 777, 733; ${ }^{1} \mathrm{H}$ NMR (300 $\left.\mathrm{MHz}, \mathrm{CDCl}_{3}\right)^{47} \delta(\mathrm{ppm}): 5.93\left(\mathrm{~s}_{\text {broad }}, 1 \mathrm{H}, \mathrm{NH}\right), 5.90-5.77(\mathrm{~m}, 1 \mathrm{H}$, CHallyl), 5.20 (dq, $J=6.5$ and $J=1.4,1 \mathrm{H}, \mathrm{CH}_{2}$ allyl $\left./ \mathrm{H}_{c i s}\right), 5.17(\mathrm{t}, J$ $=1.4,1 \mathrm{H}, \mathrm{CH}_{2}$ allyl $\left./ \mathrm{H}_{\text {trans }}\right), 4.09\left(\mathrm{dt}, J=5.5\right.$ and $\left.J=1.5,2 \mathrm{H}, \mathrm{CH}_{2}\right)$, $1.45\left(\mathrm{~s}, 6 \mathrm{H}, \mathrm{CH}_{3}\right) ;{ }^{13} \mathrm{C} \mathrm{NMR}\left(300 \mathrm{MHz}, \mathrm{CDCl}_{3}\right) \delta$ (ppm): 177.0, 156.2, 131.3, 117.7, 59.0, 40.6, 25.2; MS ESI-(+): $m / z 241[\mathrm{M}+\mathrm{H}]^{+}$.

3-Allyl-5,5-diphenylimidazolidine-2,4-dione 17 (Table 2). CAS [160448-65-7]. The reaction scale was: $0.67 \mathrm{mmol}$ (for PBM). The compound was obtained by precipitation in water; (Method B: $49.8 \mathrm{mg}, 25 \%$ yield). White solid, mp 121-123 ${ }^{\circ} \mathrm{C}$ (lit. ${ }^{48} 114-117$ $\left.{ }^{\circ} \mathrm{C}\right)$; IR $\left(\mathrm{cm}^{-1}\right)$ : $3262(\mathrm{NH}), 3091,2982,1770,1749(\mathrm{C}=\mathrm{O}), 1709$ $(\mathrm{C}=\mathrm{O}), 1494,1467,1393,1240,1182,1117,1024,801,736,702$, 664; ${ }^{1} \mathrm{H}$ NMR (300 MHz, $\left.\mathrm{CDCl}_{3}\right)^{47} \delta$ (ppm): 7.36 (s, 10H, ArH), $6.29(\mathrm{~s}, 1 \mathrm{H}, \mathrm{NH}), 5.85$ (qt, $J=10.2$ and $J=5.6,1 \mathrm{H}$, CHallyl), 5.23 (dq, $J=11.2$ and $J=1.5,1 \mathrm{H}, \mathrm{CH}_{2}$ allyl $\left./ \mathrm{H}_{\text {cis }}\right), 5.19-5.17(\mathrm{~m}, 1 \mathrm{H}$, $\mathrm{CH}_{2}$ allyl $/ \mathrm{H}_{\text {trans }}$ ), 4.18 (dt, $J=5.7$ and $J=1.5,2 \mathrm{H}, \mathrm{CH}_{2}$ ); ${ }^{13} \mathrm{C} \mathrm{NMR}$ $\left(300 \mathrm{MHz}, \mathrm{CDCl}_{3}\right) \delta(\mathrm{ppm}): 173.0,156.1,139.3,131.0,129.0$, 128.8, 127.0, 70.3, 41.1; MS ESI-(+): $m / z 293.0[\mathrm{M}+\mathrm{H}]^{+}, 265.0$.

3,5-Dibenzylimidazolidine-2,4-dione 18 (Table 2). CAS [222111-6]. The reaction scale was: $0.17 \mathrm{mmol}$ (for VBM) or $1.07 \mathrm{mmol}$ 
(for PBM). The compound was obtained by precipitation in water; (Method A: $40.5 \mathrm{mg}$ 85\% yield; Method B: $210.7 \mathrm{mg}$, 70\% yield). White solid, mp 137-139 ${ }^{\circ} \mathrm{C}$ (lit. ${ }^{49} 153-154{ }^{\circ} \mathrm{C}^{49}$ and $145-$ $\left.146^{50}\right)$; IR ( $\left.\mathrm{cm}^{-1}\right)$ : 3347, $3295(\mathrm{NH}), 3062,3031,2927,1760(\mathrm{C}=$ O), $1695(\mathrm{C}=\mathrm{O}), 1604,1495,1447,1419,1362,1341,116,1251$, 1183, 1140, 1026, 965, 930, 877, 753, 716, 669; ${ }^{1} \mathrm{H}$ NMR $(300$ MHz, DMSO- $\left.d_{6}\right)^{48} \delta(\mathrm{ppm}): 8.36(\mathrm{~s}, 1 \mathrm{H}, \mathrm{NH}), 7.25-7.17(\mathrm{~m}, 8 \mathrm{H}$, $\mathrm{ArH}), 6.78-6.76(\mathrm{~m}, 2 \mathrm{H}, \mathrm{ArH}), 4.50$ (t, $J=4.5,1 \mathrm{H}, \mathrm{C}-5 / \mathrm{CH}), 4.36$ $\left(\mathrm{q}, J=18.5,2 \mathrm{H}, \mathrm{CH}_{2}\right), 3.00\left(\mathrm{~d}, J=4.7,2 \mathrm{H}, \mathrm{CH}_{2}\right) ;{ }^{13} \mathrm{C} \mathrm{NMR}(300$ MHz, DMSO- $\left.d_{6}\right) \delta(\mathrm{ppm}): 173.2,156.2,136.3,135.0,129.9,128.3$, 128.1, 126.9, 126.8, 126.5, 57.2, 40.7, 36.1; MS ESI-(+): $m / z 281.0$ $[\mathrm{M}+\mathrm{H}]^{+}$.

3-Benzyl-5-isobutylimidazolidine-2,4-dione 19 (Table 2). The reaction scale was: $0.18 \mathrm{mmol}$ (for VBM) or $1.09 \mathrm{mmol}$ (for PBM). The compound was purified by flash chromatography (linear gradient of EtOAc in cyclohexane: 0-80\%); CAS [880487-34-3] (Method A: $29.5 \mathrm{mg}, 67 \%$ yield; Method B: $197.1 \mathrm{mg}, 74 \%$ yield). White solid, $\mathrm{mp} 114-116^{\circ} \mathrm{C}$ (lit. 79-80 $\left.{ }^{\circ} \mathrm{C}\right)$; IR ( $\left.\mathrm{cm}^{-1}\right): 3223$ $(\mathrm{NH}), 3106,2960,2872,1764(\mathrm{C}=\mathrm{O}), 1709(\mathrm{C}=\mathrm{O}), 1448,1415$, 1348, 1334, 1209, 1153, 936, 891, 879, 763, 721, 658; ${ }^{1} \mathrm{H}$ NMR (300 MHz, DMSO- $\left.d_{6}\right)^{51} \delta(\mathrm{ppm}): 8.41(\mathrm{~s}, 1 \mathrm{H}, \mathrm{NH}), 7.33-7.22(\mathrm{~m}, 5 \mathrm{H}$, $\mathrm{ArH}), 4.51$ (s, 2H, $\mathrm{CH}_{2}$ ), 4.17-4.13 (s, 1H, C-5/CH), 1.84-1.71 (m, 1H, CH), 1.58-1.35 (m, 2H, $\mathrm{CH}_{2}$ ), 0.89-0.86 (m, 6H, $\left.\mathrm{CH}_{3}\right) ;{ }^{13} \mathrm{C} \mathrm{NMR}$ (300 MHz, DMSO- $\left.d_{6}\right) \delta(\mathrm{ppm}): 174.6,156.6,136.8,128.5,127.3$, 55.0, 41.0, 40.8, 24.1, 23.1, 21.4; MS ESI-(+): $m / z 247[\mathrm{M}+\mathrm{H}]^{+}$.

3-Phenyl-5-(tert-butoxymethyl)-imidazolidine-2,4-dione 21 (Table 2). The reaction scale was: $0.17 \mathrm{mmol}$ (for VBM). The compound was purified by flash chromatography (linear gradient of EtOAc in cyclohexane: 0-40\%); $13.4 \mathrm{mg}, 30 \%$ yield. White solid, mp 101-103 ${ }^{\circ} \mathrm{C}$; IR $\left(\mathrm{cm}^{-1}\right)$ : 3326 (NH), 2970, 2919, 2850, 1783, 1708, 1597, 1494, 1414, 1363, 1336, 1284, 1237 $\left(\mathrm{C}\left(\mathrm{CH}_{3}\right)_{3}\right), 1184,1100,1086,1011,931,818,737,704,689 ;{ }^{1} \mathrm{H}$ NMR (300 MHz, $\left.\mathrm{CDCl}_{3}\right) \delta(\mathrm{ppm}): 7.53-7.31$ (m, 5H, ArH), $5.94(\mathrm{~s}$, $1 \mathrm{H}, \mathrm{NH}), 4.29(\mathrm{~m}, 1 \mathrm{H}, \mathrm{C}-5 / \mathrm{CH}), 3.82(\mathrm{dd}, J=9.2$ and $J=3.1,1 \mathrm{H}$, $\left.\mathrm{CH}_{2} / \mathrm{H}_{\mathrm{A}}\right), 3.65\left(\mathrm{dd}, J=9.2\right.$ and $\left.J=6.9,1 \mathrm{H}, \mathrm{CH}_{2} / \mathrm{H}_{\mathrm{B}}\right), 1.20(\mathrm{~s}, 9 \mathrm{H}$, $\left.\mathrm{OC}\left(\mathrm{CH}_{3}\right)_{3}\right) ;{ }^{13} \mathrm{C} \mathrm{NMR}\left(300 \mathrm{MHz}, \mathrm{CDCl}_{3}\right) \delta(\mathrm{ppm}): 171.1,156.7$, 131.6, 129.3, 128.4, 126.4, 74.2, 61.9, 58.1, 27.5; MS ESI-(+): $m / z$ $263[\mathrm{M}+\mathrm{H}]^{+}, 207$; HRMS ESI-(+): calcd for $\mathrm{C}_{14} \mathrm{H}_{18} \mathrm{~N}_{2} \mathrm{O}_{3}[\mathrm{M}+\mathrm{H}]^{+}$ 263.1396, found 263.1392.

3-Cyclohexyl-5-(4-tert-butoxybenzyl)-imidazolidine-2,4-dione 24 (Table 2). The reaction scale was: $0.43 \mathrm{mmol}$ (for PBM). 120.2 $\mathrm{mg}, 50 \%$ yield $\left({ }^{1} \mathrm{H}\right.$ NMR yield using dibromomethane $(20 \mu \mathrm{L})$ as internal standard). ${ }^{1} \mathrm{H}$ NMR $\left(300 \mathrm{MHz}, \mathrm{CDCl}_{3}\right) \delta$ (ppm): 7.08 (d, $J$ $\left.=4.5 \mathrm{~Hz}, 2 \mathrm{H}, \mathrm{ArH}^{3,5}\right), 6.92\left(\mathrm{~d}, J=4.5 \mathrm{~Hz}, 2 \mathrm{H}, \operatorname{ArH}^{2,6}\right), 5.24(\mathrm{~s}, 1 \mathrm{H}$, $\mathrm{NH})$, 4.17-4.07 (m, 1H, C-5/CH), 3.86-3.71 (m, 1H, CH), 3.15 $\left(\mathrm{dd}, J=14.0\right.$ and $\left.J=3.8,1 \mathrm{H}, \mathrm{CH}_{2} / \mathrm{H}_{\mathrm{A}}\right), 2.85(\mathrm{dd}, J=14.0$ and $J=$ 7.8, 1H, $\left.\mathrm{CH}_{2} / \mathrm{H}_{\mathrm{B}}\right)$, 1.90-1.08 (m, 19H, $\mathrm{CH}_{2}$ cyclohexyl and $\left.\mathrm{OC}\left(\mathrm{CH}_{3}\right)\right) ;{ }^{13} \mathrm{C} \mathrm{NMR}\left(300 \mathrm{MHz}, \mathrm{CDCl}_{3}\right) \delta(\mathrm{ppm}): 173.2,157.2$, 130.1, 129.8, 125.1, 124.6, 78.7, 57.6, 51.5, 37.4, 29.4, 29.2, 28.9, 26.0, 25.1; HRMS ESI-(+): calcd for $\mathrm{C}_{20} \mathrm{H}_{28} \mathrm{~N}_{2} \mathrm{O}_{3}[\mathrm{M}+\mathrm{H}]^{+}$ 345.2178 , found 345.2177 .

1-Chloro-3-ethyl-5,5' -dimethyl-2,4-imidazolidinedione 25 (Scheme 2)

Chlorination with TCCA. 3-Ethyl-5, $5^{\prime}$-dimethyl-2,4imidazolidinedione $\mathbf{1 1}$ (98 $\mathrm{mg}, 0.63 \mathrm{mmol})$ and trichloroisocyanuric acid (TCCA) $(73 \mathrm{mg}, 0.31 \mathrm{mmol}$ ) were placed into a $12 \mathrm{~mL}$ stainless steel jar with 25 stainless steel milling balls (5 mm diameter) and milled for 15 minutes at $300 \mathrm{rpm}$. Water was then added to the reaction medium and the aqueous layer was extracted with ethyl acetate. The organic layer was washed with $10 \%$ aq. citric acid and brine, dried over anhydrous $\mathrm{MgSO}_{4}$ and concentrated. The crude was purified by column chromatography (linear gradient of EtOAc in cyclohexane: 0$60 \%$ ) affording 25 as white crystals (41 mg, 34\% yield).

Chlorination with calcium hypochlorite. 3-Ethyl-5,5'-dimethyl2,4-imidazolidinedione 11 (101 $\mathrm{mg}, 0.65 \mathrm{mmol})$ and calcium hypochlorite (185 mg, $1.29 \mathrm{mmol}$ ) were placed into a $12 \mathrm{~mL}$ stainless steel jar with 50 stainless steel milling balls $(5 \mathrm{~mm}$ diameter) and milled for one hour at $450 \mathrm{rpm}$. Dichloromethane was added to the reaction medium. The precipitated inorganic salts were filtered over sintered glass and the filtrate was concentrated to yield 25 as a white solid $(107 \mathrm{mg}, 87 \%$ yield). Mp 72-74 ${ }^{\circ} \mathrm{C}$ (lit. $\left.{ }^{5} 96.6{ }^{\circ} \mathrm{C}\right)$; CAS [886757-26-2]; ${ }^{5} \mathrm{IR}\left(\mathrm{cm}^{-1}\right)$ : 3468, 3231, $2983(\mathrm{NH}), 2938,1770(\mathrm{C}=\mathrm{O}) ; 1700(\mathrm{C}=\mathrm{O}) ; 1442$, 1411, 1379, 1341, 1293, 1229, 1208, 1161, 1067, 1001, 943, 881, 833, 757, 729; ${ }^{1} \mathrm{H}$ NMR (300 MHz, $\left.\mathrm{CDCl}_{3}\right)^{48} \delta(\mathrm{ppm}): 3.61$ (q, $J=$ $\left.7.2,2 \mathrm{H}, \mathrm{CH}_{2}\right), 1.45\left(\mathrm{~s}, 6 \mathrm{H}, \mathrm{CH}_{3}\right), 1.22\left(\mathrm{t}, J=7.2,3 \mathrm{H}, \mathrm{CH}_{3}\right) ;{ }^{13} \mathrm{C}$ NMR (300 MHz, $\mathrm{CDCl}_{3}$ ) $\delta$ (ppm): 174.3, 154.7, 65.9, 34.9, 22.3, 13.5; MS ESI-(+): $m / z$ for ${ }^{35} \mathrm{Cl} /{ }^{37} \mathrm{Cl} 191 / 193[\mathrm{M}+\mathrm{H}]^{+}$; HRMS ESI(+): calcd for $\mathrm{C}_{7} \mathrm{H}_{11} \mathrm{~N}_{2} \mathrm{O}_{2} \mathrm{Cl}[\mathrm{M}+\mathrm{H}]^{+}$191.0587, found 191.0587 .

1-Chloro-3-allyl-5,5' -dimethyl-2,4-imidazolidinedione $\quad 26$ (Scheme 2). Chlorination was performed with calcium hypochlorite starting from 3-allyl-5,5-dimethylimidazolidine-2,4dione 16. The reaction scale was $0.179 \mathrm{mmol}$. The final product was recovered by precipitation $(0.181 \mathrm{mg}$, $99 \%$ yield $)$, as previously described for compound 25. CAS [1174756-67-2]. White solid, mp 68-70 ${ }^{\circ} \mathrm{C}$; IR $\left(\mathrm{cm}^{-1}\right)$ : 3471, $3099(\mathrm{NH}), 2995$, 2940, 1774 (C=O), 1714 (C=O), 1648, 1413, 1398, 1327, 1226, 1165, 1135, 944, 912, 876, 824, 758, 728; ${ }^{1} \mathrm{H}$ NMR $(300 \mathrm{MHz}$, $\left.\mathrm{CDCl}_{3}\right) \delta(\mathrm{ppm}): 5.88-5.75$ (m, 1H, CHallyl), 5.27-5.25, 5.25-5.23 $\left(\mathrm{m} \times 2,1 \mathrm{H}, \mathrm{CH}_{2}\right.$ allyl $\left./ \mathrm{H}_{\text {cis }}\right), 5.21-5.19\left(\mathrm{~m}, 1 \mathrm{H}, \mathrm{CH}_{2}\right.$ allyl $\left./ \mathrm{H}_{\text {trans }}\right)$, 4.15 (dt, $\left.J=6,2 \mathrm{H}, \mathrm{CH}_{2}\right), 1.47\left(\mathrm{~s}, 6 \mathrm{H}, 2 \times \mathrm{CH}_{3}\right) ;{ }^{13} \mathrm{C} \mathrm{NMR}(300$ $\left.\mathrm{MHz}, \mathrm{CDCl}_{3}\right) \delta$ (ppm): 174.2, 130.8, 119.0, 66.2, 41.9, 22.5; MS ESI-(+): $m / z$ for ${ }^{35} \mathrm{Cl} /{ }^{37} \mathrm{Cl} 203 / 205,175,169,130$; HRMS ESI- $(+)$ : calcd for $\mathrm{C}_{8} \mathrm{H}_{12} \mathrm{~N}_{2} \mathrm{O}_{2} \mathrm{Cl}[\mathrm{M}+\mathrm{H}]^{+}$203.0587, found 203.0589.

\section{Notes and references}

1 M. Meusel and M. Gutschow, Org. Prep. Proced. Int., 2004, 36, 391-443.

2 W. J. Close, Anticonvulsant 3-ethyl-5-phenyl hydantoin unit dosages and method of using same, US 2793157 A, 1957.

3 M. Moguilewsky, J. Fiet, C. Tournemine and J. P. Raynaud, J. Steroid. Biochem., 1986, 24, 139-146.

4 G. Xi, Y. Xiu, L. Wang and X. Liu, J. Appl. Polym. Sci., 2015, 132, 41821-41827.

5 Z. Chen and Y. Sun, Ind. Eng. Chem. Res., 2006, 45, 26342640.

6 D. A. Babkov, A. O. Chizhov, A. L. Khandazhinskaya, A. Corona, F. Esposito, E. Tramontano, K. L. Seley-Radtke and M. S. Novikov, Synthesis, 2015, 47, 1413-1422.

7 A. Martinez, M. Alonso, A. Castro, I. Dorronsoro, J. L. Gelpi, F. J. Luque, C. Perez and F. J. Moreno, J. Med. Chem., 2005, 48, 7103-7112. 
8 C. Pedregal, G. G. Trigo, M. Espada, J. Elguero, E. J. Vincent and R. Faure, J. Heterocycl. Chem., 1984, 21, 477-480.

9 J. H. Poupaert, C. Smeyers and P. Bottcher, Bull. Soc. Chim. Belg., 1985, 94, 431-434.

10 M. J. O. Anteunis, L. Spiessens, M. De Witte, R. Callens and F. Reyniers, Bull. Soc. Chim. Belg., 1987, 96, 459-465.

11 M. L. Sanders and I. O. Donkor, Synth. Commun., 2002, 32, 1015-1021.

12 N. Dieltiens, D. D. Claeys, V. V. Zhdankin, V. N. Nemykin, B. Allaert, F. Verpoort and C. V. Stevens, Eur. J. Org. Chem., 2006, 2649-2660.

13 D. Blanco-Ania, P. H. H. Hermkens, L. A. J. M. Sliedregt, H. W. Scheeren and F. P. J. T. Rutjes, J. Comb. Chem., 2009, 11, 527-538.

14 J. A. d. S. Luis, J. M. Barbosa Filho, B. F. Lira, I. A. Medeiros, L. C. S. Lima de Morais, A. F. Ernandes dos Santos, C. Soares de Oliveira and P. Filgueiras de Athayde-Filho, Molecules, 2010, 15, 128-137.

15 J. M. Fraile, G. Lafuente, J. A. Mayoral and A. Pallares, Tetrahedron, 2011, 67, 8639-8647.

16 H. S. G. Beckmann, F. Nie, C. E. Hagerman, H. Johansson, Y. S. Tan, D. Wilcke and D. R. Spring, Nat. Chem., 2013, 5, 861-867.

17 F. Fujisaki, K. Toyofuku, M. Egami, S. Ishida, N. Nakamoto, N. Kashige, F. Miake and K. Sumoto, Chem. Pharm. Bull., 2013, 61, 1090-1093.

18 W. Karnbrock, M. Deeg, J. Gerhardt and W. Rapp, Mol. Diversity, 2000, 4, 165-171.

19 K. H. Park and M. J. Kurth, Tetrahedron Lett., 2000, 41, 74097413.

20 Z. Zhai, J. Chen, H. Wang and Q. Zhang, Synth. Commun., 2003, 33, 1873-1883.

21 G. J. T. Kuster, L. W. A. van Berkom, M. Kalmoua, A. Van Loevezijn, L. A. J. M. Sliedregt, B. J. Van Steen, C. G. Kruse, F. P. J. T. Rutjes and H. W. Scheeren, J. Comb. Chem., 2006, 8, 85-94.

22 E. Colacino, F. Lamaty, J. Martinez and I. Parrot, Tetrahedron Lett., 2007, 48, 5317-5320.

23 P. Y. Chong and P. A. Petillo, Tetrahedron Lett., 1999, 40, 2493-2496.

24 L. Hroch, M. Hruskova, J. Schmitz, G. Schnakenburg and M. Guetschow, Synthesis, 2012, 44, 1907-1914.

25 B. Tao and J. W. Timberlake, Synthesis, 2000, 1449-1453.

26 D. Zhang, X. Xing and G. D. Cuny, J. Org. Chem., 2006, 71, 1750-1753.

27 X. Teng, A. Degterev, P. Jagtap, X. Xing, S. Choi, R. Denu, J. Yuan and G. D. Cuny, Bioorg. Med. Chem. Lett., 2005, 15, 5039-5044.

28 P. M. Fresneda, P. Molina and M. A. Sanz, Tetrahedron Lett., 2001, 42, 851-854.
29 A. Bolognese, G. Correale, M. Manfra, A. Esposito, E. Novellino and A. Lavecchia, J. Med. Chem., 2008, 51, 8148-8157.

30 L. Konnert, B. Reneaud, R. M. de Figueiredo, J.-M. Campagne, F. Lamaty, J. Martinez and E. Colacino, J. Org. Chem., 2014, 79, 10132-10142.

31 D. Hasa, G. S. Rauber, D. Voinovich and W. Jones, Angew. Chem., Int. Ed., 2015, 54, 7371-7375.

32 V. Declerck, E. Colacino, X. Bantreil, J. Martinez and F. Lamaty, Chem. Commun., 2012, 48, 11778-11780.

33 L. Konnert, A. Gauliard, F. Lamaty, J. Martinez and E. Colacino, ACS Sustainable Chem. Eng., 2013, 1, 1186-1191. 34 L. Konnert, F. Lamaty, J. Martinez and E. Colacino, J. Org. Chem., 2014, 79, 4008-4017.

35 M. Lanzillotto, L. Konnert, F. Lamaty, J. Martinez and E. Colacino, ACS Sustainable Chem. Eng., 2015, 3, 2882-2889.

36 K. H. Dudley and D. L. Bius, J. Heterocycl. Chem., 1973, 10, 173-180.

37 H. Liu, Z. Yang and Z. Pan, Org. Lett., 2014, 16, 5902-5905.

38 J. Chen, S. K. Spear, J. G. Huddleston and R. D. Rogers, Green Chem., 2005, 7, 64-82.

39 K. Knop, R. Hoogenboom, D. Fischer and U. S. Schubert, Angew. Chem., Int. Ed., 2010, 49, 6288-6308.

40 E. Colacino, J. Martinez, F. Lamaty, L. S. Patrikeeva, L. L. Khemchyan, V. P. Ananikov and I. P. Beletskaya, Coord. Chem. Rev., 2012, 256, 2893-2920.

41 G. Giachi, M. Frediani, W. Oberhauser, F. Lamaty, J. Martinez and E. Colacino, ChemSusChem, 2014, 7, 919924.

42 G. Cravotto and P. Cintas, Chem. Sci., 2012, 3, 295-307.

43 H. A. Klok and J. Genzer, ACS Macro Lett., 2015, 4, 636-639. 44 A. S. Geneidi, A. A. Ali and R. B. Salama, J. Pharm. Sci., 1978, 67, 114-116.

45 F. L. Guedes, B. G. de Oliveira, M. Z. Hernandes, C. A. De Simone, F. J. B. Veiga, M. d. C. A. de Lima, I. R. Pitta, S. L. Galdino and P. J. R. Neto, AAPS PharmSciTech, 2011, 12, 401-410.

46 S. M. Dumbris, D. J. Diaz and L. McElwee-White, J. Org. Chem., 2009, 74, 8862-8865.

47 G. Xi, Y. Xiu, L. Wang and X. Liu, J. Appl. Polym. Sci., 2015, 132, 41824.

48 N. Trisovic, T. Timic, J. Divljakovic, J. Rogan, D. Poleti, M. M. Savic and G. Uscumlic, Monatsh. Chem., 2012, 143, 1451-1457.

$49 \mathrm{H}$. Aspelund and P. Waselius, Resistance of hydantoins and 5-hydroxyhydantoins to alkali, Acta Acad. Abo., Ser. B, 1967, (6), 27; II.

50 H. L. Finkbeiner, FR 1389841, 1965.

51 D. Zhang, X. Xing and G. D. Cuny, J. Org. Chem., 2006, 71, 1750-1753. 